\title{
光学活性ポリ( $\beta$-メチルグリシド酸アルキルエステル)の合成*1
}

(昭和 40 年 11 月 9 日受理)

島崎秀雄*2

光学活性 $\beta$-メチルグリシド酸メチルエステルから光学活性のポリエーテルを合成した。重合蚛媒としては, 三フッ化本ウ素エ ーテラート，四塩化スズが箸合活性高く前者は室温以下の低温ですでに重合反応を行ない，光学活性ポリマーを与えたが，トリメ

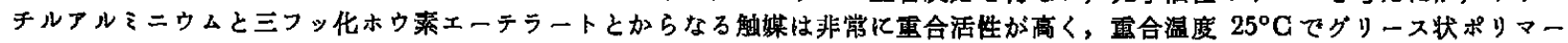

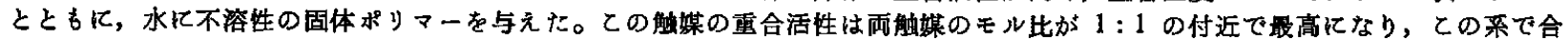
成した固体ポリマーの纤旋光度 $[\alpha]^{25^{\circ} \mathrm{C}}$ は, 塩化メテレン中で $-36.9^{\circ}$ であった。またとのポリマーの粘度測定から得た嗃元粘度

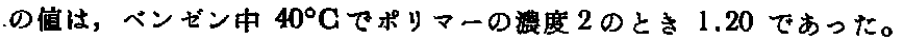

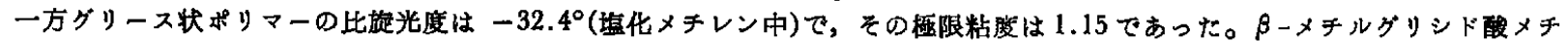
ルエステルは,トリエテルアルミニウムー水系触媒, トリエチルアルミニウムと漂移金属化合物系触媒によっても重合し，光学活

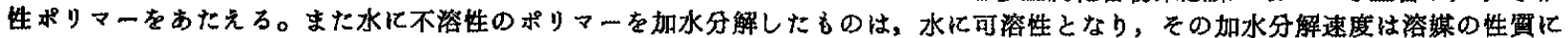

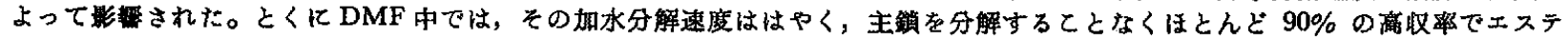
ル基は加水分解をうける。さらに NMR スペクトル，IR スペクトル，ORD スペクトルなどを測定して合成したポリェーテルの 性䨘を検詩した。

\section{1 緒事}

前報で著者は，D-スレオニンから光学活性な $\beta$-メチルグリシ ド酸メチルエステル(本報では $\beta$-MGAM と略す)を合成するこ とについて報告した。これをモノマーとして，その光学活性を保 持したまま間理重合を行なえば官能基をむった光学活性なポリエ 一テルを得ることができるであろう。このポリマーは，主鎖の不 整炭素に直結したカルボキシル基をるつ線状ポリマーであるため に，光学的に不整なイオン交換を行なうことが期待される。

従来プロピレンオキシドやエチレンオキシドのような糫状エー テルのイオン重合については多くの研究が報告されている1 8)。 また光学活性なプロピレンオキシドの重合反応や光学活性触媒を 用いての光学活性 ポリエーテルへの不整誘導重合の研究らすあ る。しかし $\beta$-MGAM のように官能基としてカルボキシル基を もつ光学活性ポリエーテルの研究は, 著者らの知るかきりまだ報 告されていない。

本報では, 光学活性 $\beta$-MGAM から光学活性ポリエーテルを 合成すること，および生成ポリマーの性質について報告する。

\section{2 実 殹 の 部}

\section{1 溶 媒}

DMF*3: ベンゼンといっしょに蒸留し，ついで窒素気流中で 分留して精製した。

THF*4: 水酸化カリウムで処理したのち，金属ナトリウム上 で適流し脱水する。とれにベンゾフェノンを加え, THF が青色 になるまで薑流し，公素気流中で蒸留した。

ベンぜン: 常法にしたがって精製した。

*1との赫交を“光学活性ポリエーテルの合成(第 2 派)”と する；前報(第 1 報)，泉崎，日化，87，459(1966).

*2 Hideo SHIMASAKI 味の素株式会社中央矿究所, 川崎市 鈴木町

1) H. Staudinger, Angew. Chem., 73, 177(1961),

2) M. Osgan, C. C. Price, J. Polymer Sci., 34, 153(1959).

3) P. E. Ebert, C. C. Price, ibid., 34, 157(1959).

*3シメチルホルムアる゙・.

*4 テトラヒドロフラン.
他の溶媒: 市販品を必要に応じて精彆して使用した。

\section{2 触 媒}

トリエチルアルミニウム：市販品(Ethyl Corporation 製)をそ のままべンゼンに溶かし，その䟴度が $1 \mathrm{~mol} / l$ になるように調 製した。

ジエチル亜鉛: 市販品(Ethyl Gorporation 製)を精製すること なくベンゼンに溶かし， $2 \mathrm{~mol} / l$ の溶液として使用した。

トリエチルアルミニゥムー水系触媒(): 十分に 乾燥した フラス コに反応溶媒を適当量の水ととむに入れ, $-78^{\circ} \mathrm{G}$ に冷やしのた ち，かきまぜながらトリエチルアルミニウムを加え， 1.5 時間室 温に放䈯する。反应液はただちに口過し，口液と沈段とをそれぞ れ触媒として使用した。

三壏化鉄コンプレックス触媒7): $1.0 \mathrm{~g}$ の無水塩化鉄を $5 \mathrm{ml}$ の 精製ベンゼンに溶かし，これにゆっくり $1.0 \mathrm{~g}$ のプロピレンオキシ ドをかきまぜながら加える。この際反応温度を $60^{\circ}$ 〜 $70^{\circ} \mathrm{C}$ に調節 し,さらに20〜30分の間空温にたもった。反応混合物を減圧蒸留し て揮発性物質をのぞいたのち, 得られた茶褐色残留物灾触媒とし て使用した。さらに, プロピレンオキシドのかわりに $\beta$-MGAM を使用して調製した茶褐色残留物を触煤として使用した。

\section{3 単是体}

P-MGAM: 前報にしたがって合成した $\beta$-MGAM 2 度蒸 留して, $50^{\circ} \sim 50.5^{\circ} \mathrm{C}(8 \mathrm{mmHg})$ の留分を集めた。純度はガスク ロマトグラフィーで検討して，99\% 以上のものを使用した。

\section{4 而反流}

2.4.1 アンプル重合法：比較的高温での重合反応はアンプル 中で行なった。図1に示したアンプルにドライアイスで冷やしな がら望素刹流下，注射器で触媒を滴下吋る。しかるのち封管して 所定の温度で一定洔間反応にあてる。

4) C. C. Price, M. Osgan, J. Am. Chem. Soc., 78, 4787 (1956).

5) 准田, 井上, 吉田, 工化, 67，1439(1964); Makromol. Chem., 79, 34(1964).

6) T. Saegusa, H. Imai, J. Furukawa, Makromol. Chem., 53,203 (1962); 65, 60(1963).

7) M. E. Pruitt, J. M. Baggett, U. S. P., 2,811,491 (1957). 


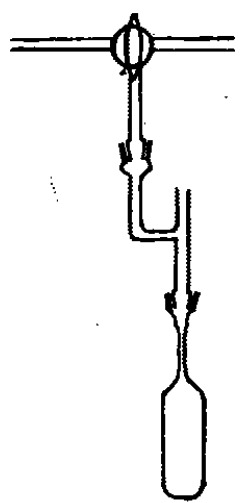

アンプル電合法

図 1 重合反俯装装

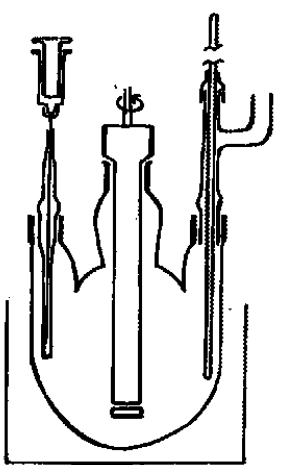

フラスコ雷合法

図 2 重合反纫装置

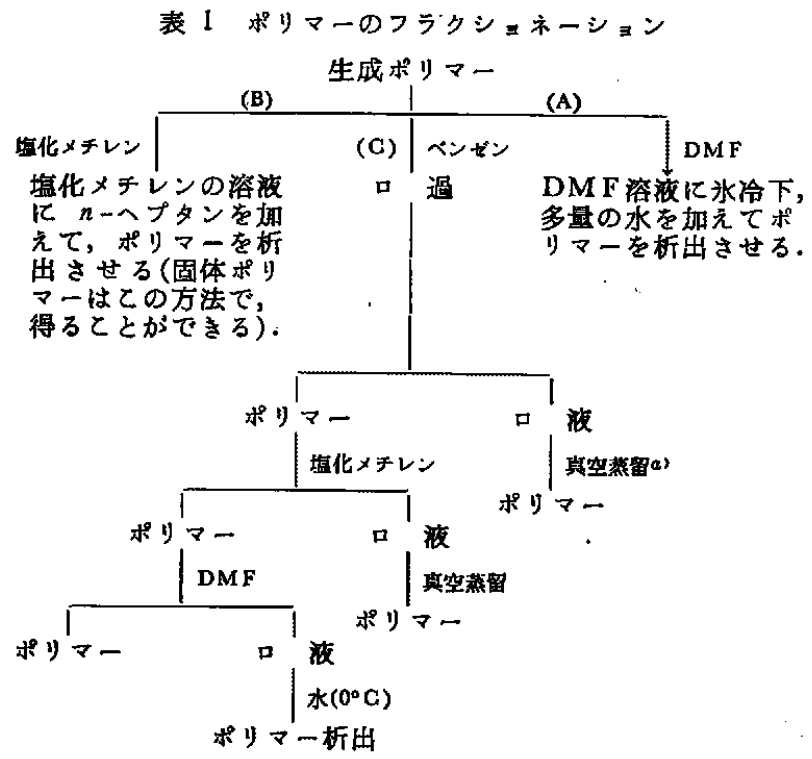

（1）必要に店じて(A)，(B)，(C)法にしたがってポリマ 一を分锥した。

注 a) 室温で凍結乾噪.

2.4.2 フラスコ贯合法：低温重合ではフラスコを使讲した。 因1に示したような三つロフラスコにまず邢当量の溶媒とモノマ 一とを入れ，ドライアイス/メタノールで冷却しながら，窒装気 流下触媒を滴下する。1 淮ドライアイス上で放置したのち, 所定 時間，一定の温度で反応させる。この重合反心ははトリチルア

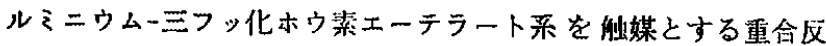
応に適用したもので，他の触媒を使用した場合や融点の高い溶媒 を使朋したときは，必ずしもドライアィスで冷やす必要はない。 比較的低盢での高合反応では，操作がしやすいという点でフラス コを使用した。

\section{5 畐合体の精製}

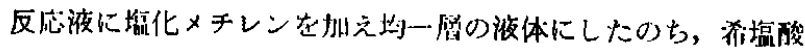

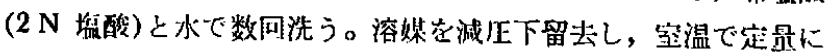
なるまで減成下にたむつ(㶱絬乾燥法)

\section{6 精製直会体の fractionation}

表】に示したす泝にしたがって行なった。

\section{7 自含体の粘度の測定}

精製ベンゼンあるいは DMF を溶媒として恒温棈中で測定し
た。重合体は分解を防ぐために室温で溶かした。ポリエーテルの 極限粘度と分子量との関俰式として，Bailey の式名があるか，本 報のようにメチル基，エステル基を主銧に有するポリエーテルに は適用されないであろう。

\section{8 比旋光度の湘定}

比旋光度は Zeiss Winkel を使用して測定した。塩化メチレン あるいは DMF 溶媒として使用した。着色重合体の旅光度は ETL-NPL automatic polarimeter $143 \mathrm{~A}$ を使用して測定した。

\section{9 亚合体の $\mathrm{x}$ 線スペクトルの湖定}

X 線スペクトルは, Geigerflex diffractometer(理学電気笠)を 使用して測定した。その際 Nickel filtered GuK radiation 使 用した。

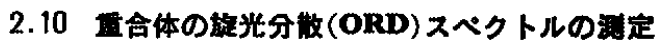

ORD/UV-5(日本分光製)で，ORD スペクトルを測定した。

\subsection{1 息合体の赤外㖟収スペクトルの湖定}

IR-Spectrophotometer EPI-2(日立製)と简易型 IR-Spectrophotometer (日本分光製)とを使用した。グリース状重合体は液儤 法で，固体重合体は真化カリウム鋜剂として測定した。

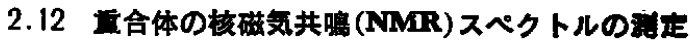

重合体の NMR スペクトルは, Varian-60A を使用して測定 した。

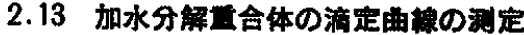

加水分解した 重合体の滴定曲線は, Potentiograph(E 336 型) (Metrohm 社製)を使用して測定した。

\section{3 结果および考樈}

\section{1 無機金压船媒}

3.1 .1 一元触媒: $\beta$-MGAM は土チレンオキシド, プロピレ ンオキシドほどに重合活性は高くなかった。たとえば表 2 に示す ように, 水酸化カりウム, 金属カリウム, 塩化鉄, 塭化アル ウムなどの無機触媒はほとんど重合反応を起さなかった。重合活 "性触媒としては，四壏化スズ，四塩化チタン，三軽化チタン，三 フッ化ホウ素を挙げることができるが,なかでも四垣化スズ、三 フッ化ホウ䒺エーテラートは, 他の重合触媒と比较して重合活性 が高く, 前者は高温で重合反応を起し，後者は室温ですでに高重 合体をあたえた。もちろん三フッ化ホウ素エーテラートも高温で 重合活性を示すが高重合体をあたえない。表 3 に示すように高温 重合反応はおお゙よそ $100^{\circ} \sim 60^{\circ} \mathrm{G}$ の温度範囲で行なかれる反応 であり，それ以上の温度では反応速度ははやくなるが，解重合も いちじるしく起るようになり，高収率で重合度の高いポリマーを 得ることができなくはる。

シフッ化ホウ素エーテラートの重合反応は最初室温以下で行な うことが必要であり，触媒を仕込むときは少なくともドライアイ ス上で冷やしながらゆっくり滴下し徐々に温度を上げることによ つて高重命体在得むこよができる。上記種類の钫媒によって得ら れたボリマーはいずれも水に可溶性の淡黄色，無定形のグリース 状ボリマーてその尔外吸収スペクトルは二重結合の㚬い吸收およ び水酸些す吸収スペクトルを示している(図6)。

シフッ化ホウ素エーテラートによる重合反応は，つぎのような 北質它もっている。

8) F. E. Bailey, L. G. Imhof, J. Polymer Sci., 32, 517 
表 2 無僟能飞よる電合反庞 $\mathrm{M} / \mathrm{C}:$ モノマ/触媒（モル比）

\begin{tabular}{|c|c|c|c|c|c|}
\hline 触弩 & $\mathrm{M} / \mathrm{C}$ & 溶 媒 & 時 間 & $\frac{\text { 温 }}{\left({ }^{\circ} \mathrm{C}\right)}$ & 結 \\
\hline $\mathrm{K}$ & 50 & $\mathrm{C}_{6} \mathrm{H}_{\varepsilon}$ & $18 \sim 20 \mathrm{hr}$ & 25 & ポリマーはまったく得られない（収率=0\%） \\
\hline $\mathbf{K O H}$ & 65 & $\mathrm{C}_{6} \mathrm{H}_{6}$ & $24 \mathrm{hr}$ & 70 & $(1 ")$ \\
\hline $\mathrm{CuO}$ & 65 & $\mathrm{C}_{6} \mathrm{H}_{6}$ & $24 \mathrm{hr}$ & 70 & ポリマーは得られなかった。 \\
\hline $\mathrm{Fe}_{2} \mathrm{O}_{5}$ & 65 & なし & $24 \mathrm{hr}$ & 70 & " \\
\hline $\mathrm{FeCl}_{3}$ & 50 & $\mathrm{C}_{6} \mathrm{H}_{6}$ & $16 \sim 20 \mathrm{hr}$ & 50 & 少量のポりマーが得られた. \\
\hline $\mathrm{FeCl}_{\mathbf{8}}$ & 72 & なし & $2 \sim 3$ day & 80 & （収率 $=7 \%$ ) \\
\hline active $\left.\mathrm{FeCl}_{8}{ }^{a}\right)$ & 80 & " & $2 \sim 3$ day & 80 & （収率 $=8 \%$ ) \\
\hline $\mathrm{AlCl}_{3}$ & 80 & " & $2 \sim 3$ day & 80 & ポリマーはまったく得られなかった（収率う0\%) \\
\hline $\mathrm{LiCl}$ & 80 & $"$ & $2 \sim 3$ day & 80 & $"$ ) \\
\hline $\mathrm{ZnCl}_{2}$ & 60 & " & 1 day & 70 & ポリマーは得られなかった（取率=0\%) \\
\hline $\mathrm{M}_{3} \mathrm{PO}_{4}$ & 60 & " & 1 day & 60 & (収率 $1 \%$ ) \\
\hline $\mathrm{CaSO}_{4}$ & 80 & $"$ & I day & 60 & " \\
\hline
\end{tabular}

注 a）实験の項で述べた方法にしたがって，プロピレンオキシド(あるいは $\beta$-MGAM)によって処理した塩化鉄触媒.

表 $3 \quad \mathrm{BF}_{3} \mathrm{O}\left(\mathrm{C}_{2} \mathrm{H}_{5}\right)_{2}$ を触媒とする重合反応（その1）

$\mathbf{M} / \mathbf{C}:$ モ マー/触媒のモ认此

$[\alpha]_{D}^{25{ }^{\circ} \mathrm{C}}$ : 塭化メチレン中のポリマーの比旋光度

収率：モノマーに対するポリマーの全収率

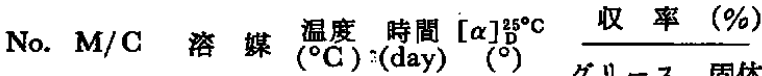

$\begin{array}{rrlrllll}8 & 80 & \mathrm{C}_{6} \mathrm{H}_{6} & 25 & 4 & -22.5 & 25 & 0 \\ 15 & 80 & \text { な し } & 25 & 4 & -22.0 & 30 & 0 \\ 36 & 40 & \mathrm{CH}_{2} \mathrm{Cl}_{2} & 25 & 4 & -23.3 & 32 & 0 \\ 37 & 40 & \mathrm{C}_{6} \mathrm{H}_{6} & 25 & 6 & -20.0 & 35 & 0 \\ 38 & 80 & \text { エーテル } & 25 & 6 & -22.0 & 30.5 & 0 \\ 39 & 40 & \text { は し } & 60 & 2 & -18.5 & 30.2 & 0 \\ 41 & 80 & \mathrm{C}_{6} \mathrm{H}_{6} & 80 & 2 & -15.8 & 42.8 & 0 \\ 42 & 180 & \text { な し } & 100 & 2 & -15.0 & 55.0 & 0\end{array}$

表 4 四壏化スズを能媒とする重合反応

反応条件 浴媒: ベンゼン，モノマー/触媒のモル比: 100〜120, アンプル重合.

比旋光度は壏化メヂレン中のポリマーの旋光度で $[\alpha]_{\mathrm{D}}^{25^{\circ} \mathrm{C}}$ の值を示す。

$\eta_{\mathrm{sp}} / \mathrm{c}: 40^{\circ} \mathrm{C}$ ，ベンゼン中での值でポリマー浱度は $2 \mathrm{~g} /$ $100 \mathrm{ml}$ である(粘度はすべてての濃度で測定した）。

$\begin{array}{lccccc}\text { No. } & \begin{array}{c}\text { 反岕温度 } \\ \left({ }^{\circ} \mathrm{C}\right)\end{array} & \begin{array}{c}\text { 反㐫時間 } \\ (\text { day })\end{array} & \begin{array}{c}\text { 全収率 } \\ (\%)\end{array} & \begin{array}{c}\eta_{\mathrm{sp}} / c \\ (c=2)\end{array} & \text { 比旋光度 } \\ \text { P-1 } & 80 & 3 & 25 & 0.48 & -19.5 \\ \text { P-2 } & 50 & 3 & 10.5 & 0.42 & -20.0 \\ \text { P-3 } & 25 & 4 & 7.0 & 0.49 & -19.4 \\ \text { P-4 } & 100 & 3 & 25.0 & 0.39 & -18.6\end{array}$

1）一定時間後のポりマーの収率はモノマー浱度にあまり関係 しない(表 5 )。

2）触媒浱度の增加とともに反応速度は上昇したが，重合度は 逆に低下した(図 3,4)。

3）反応温度の上昇とともに，ポリマーの比旋光度はいちじる しく減少した。一方反応速度は增大した(表 3，5)（図 5)。

3）の旋光度の減少性重含度の減少に基ういていると思われる。 一方四塩化スズで合成したポリマーと三フッ化ホウ素エーテラー トで合成したポリマーの比旋光度の䵇は，両ポリマーがほとんど

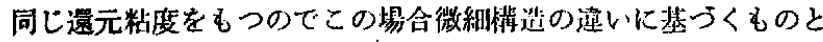
思われる。したがって高温では三フッ化ホウ素エーテラートは，

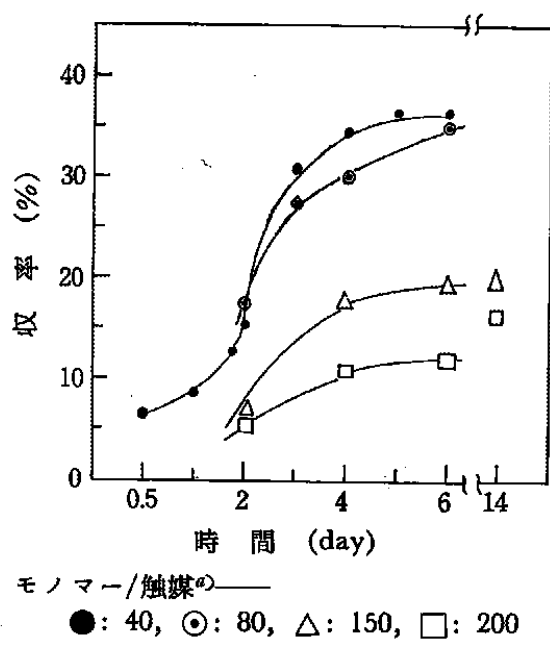

重合条件一

反忘温度: $25^{\circ} \mathrm{C}$, 触媒: $\mathrm{BF}_{3} \mathrm{O}\left(\mathrm{C}_{2} \mathrm{H}_{5}\right)_{2}$

図 3 触新灌度と反虑速度との関係

注 a) モル比を示す。

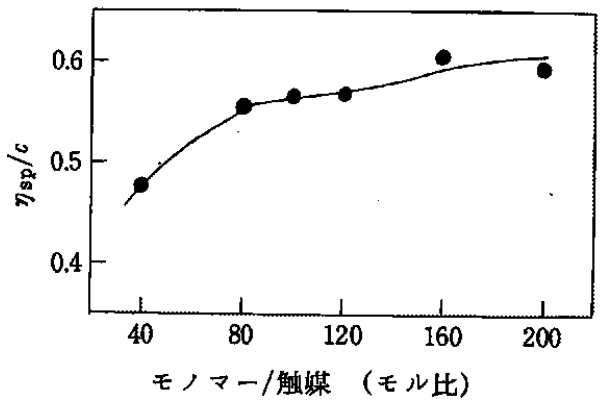
電合条件等

$\eta_{\mathrm{sp}} / c:$ ベンゼン中, $40^{\circ} \mathrm{C}, c=2$ のときの值

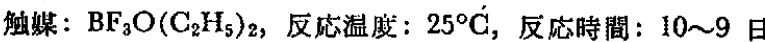

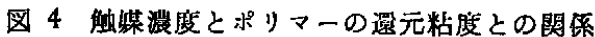

四塩化スズほどに立体的規則性を規制しない触媒であると推測さ れる。しかし，ポリマーの這元粘度と比旋光度のみからこのよ うに推定することは非常に危険であり，今後こうした触媒の特刑 について，さらに倹討していくつもりである。 
表 $5 \quad \mathrm{BF}_{3} \mathrm{O}\left(\mathrm{C}_{2} \mathrm{H}_{5}\right)_{2}$ を能煤とする重合反応（その 2）

溶媒：ベンゼン，全収率：モノマーに対するポリマーの取繁， $\eta_{\mathrm{sp}} / c: 40^{\circ} \mathrm{C}$, ペンゼン中の傎. $[\alpha]_{\mathrm{D}}^{25^{\circ} \mathrm{C}}$ : 塩化メチレン中に 把ける值，モノマー/做媒(モル比)：100

\begin{tabular}{|c|c|c|c|c|c|c|}
\hline No. & $\begin{array}{l}\text { 反庶 } \\
\text { 温度 } \\
\left({ }^{\circ} \mathrm{C}\right)\end{array}$ & $\begin{array}{l}\text { 反底 } \\
\text { 時䦧 } \\
\text { (day) }\end{array}$ & $\begin{array}{l}\text { 溶媒/ } \\
\text { ； } \\
(\mathrm{v} / \mathrm{v})\end{array}$ & $\begin{array}{c}\text { 全收潘 } \\
(\%)\end{array}$ & $\begin{array}{l}\eta_{\mathrm{sp}} / c \\
(c=2)\end{array}$ & $\begin{array}{c}{[\alpha]_{0}^{25^{\circ} \mathrm{C}}} \\
\left({ }^{\circ}\right)\end{array}$ \\
\hline B -1 & 25 & 10 & 0 & 30.1 & 0.54 & -23.0 \\
\hline B -2 & 25 & 10 & 0.5 & 29.4 & 0.46 & -21.9 \\
\hline$B-3$ & 25 & 10 & 1.0 & 33.3 & 0.56 & -22.4 \\
\hline B - -4 & 25 & 10 & 2.0 & 32.7 & 0.59 & -23.0 \\
\hline B -10 & 60 & 2 & 1.0 & 30.0 & 0.35 & -18.0 \\
\hline$B-11$ & 80 & 2 & 1.0 & 41.8 & 0.42 & -15.8 \\
\hline B-12 & 80 & 3 & 0 & 43.0 & 0.47 & -16.1 \\
\hline B - 13 & 100 & 3 & 1.0 & 56.1 & 0.30 & -15.1 \\
\hline
\end{tabular}

表 $6 \mathrm{AlEt}_{3}$ 亿よる軍合反応

No. 12，7 は触媒として $\mathrm{ZnEt}_{2}$ を使用.

No. 10 は $\mathrm{ZnEt}_{2}$-EtOH 系を触媒とする反応.

No. 2, 9 は $\mathrm{Al}\left[\mathrm{OCH}\left(\mathrm{CH}_{3}\right)_{2}\right]_{3}$ 触媒とする反応.

いずれもアンプル重合である。

比旋光度: $[\alpha]_{\mathrm{D}}^{25^{\circ} \mathrm{C}}$ の值 $\left(\mathrm{CH}_{2} \mathrm{Cl}_{2}\right)$

\begin{tabular}{|c|c|c|c|c|c|c|}
\hline No. & モノマ- & 溶 媒 & $\left({ }^{\circ} \mathrm{C}\right)$ & $\begin{array}{l}\text { 時間 } \\
\text { (day) }\end{array}$ & $\begin{array}{c}\text { ポりマ } \\
\text { 一収率 } \\
(\%)\end{array}$ & $\begin{array}{l}\text { 皆 } \\
\text { 光度 } \\
\left({ }^{\circ}\right)\end{array}$ \\
\hline 6 & 80 & $\mathrm{C}_{6} \mathrm{H}_{6}$ & 25 & 14 & $0.7 \sim 0.8$ & \\
\hline 11 & 65 & \& 2 & 80 & 13 & $5 \sim 7$ & \\
\hline 13 & 125 & " & 80 & 13 & 10 & -23.3 \\
\hline 18 & 80 & " & 100 & 13 & 7.5 & \\
\hline 19 & 80 & " & 120 & 13 & 12.5 & -20.5 \\
\hline 20 & 60 & " & 80 & 17 & 8.7 & -20.0 \\
\hline 12 & 65 & " & 80 & 13 & 3〜4 & \\
\hline 7 & 80 & $\mathrm{C}_{6} \mathrm{H}_{3}$ & 25 & 14 & $0.9 \sim 1$ & \\
\hline 10 & 128 & な ᄂ & 65 & 13 & 5 & \\
\hline 2 & 50 & $\mathrm{C}_{6} \mathrm{H}_{6}$ & 50 & $20 \mathrm{hr}$ & 0 & \\
\hline 9 & 62 & な し & 80 & 13 & 0 & \\
\hline
\end{tabular}

\section{2 有機金属触媒}

3.2 .1 単一触媒: トリェチルアルミニウムやジェチル西鉛の ような有機金属化合物はそれ自身では高い重合活性はなく，誘道 期間の延長をもたらし，重合特間を長くすると若干の光学活性ポ リマーを与えた。表に示すように反応時間は普通 10〜20 日間 で，それ以後もほとえど重合速度の上昇は認められなかった。そ れ以前ではほとんどポりマーを認めることができず，温度を $100^{\circ}$ 〜 $150^{\circ} \mathrm{G}$ に上げても結果は同じであった。トリエチルアルミニ ウムによる最高収率はモノマーに対して 10〜15\%くらいであっ た。得られたポリマーは，いずれもグリース状ポリマーで水に可 溶性であり粘度も低く，その物理的性質にとくにいもじるしい特 長はなかった。

3.2 .2 共触媒: 上述した単一触媒は重合活性が低かったが， てれら有機金属を三フッ化ホウ菜エーテラート，あるいは四塭化 スズといっしょに使用すると，非常に光学活性の高いポリマーを 得ることができる。重合反応は二つの触媒を注射器で別々に速続 して系内に注入して行ない，トリエチルアルミニウム(あるいは ジェチル覀鉛)をまずドライアイス上で泠却した反応液に注入し， 十分にかきまぜたのち，三フッ化ホウ素エーテラート(あるいは 四塭化スズ)をゆっくり注入するやり光がもっとも好むしい。器 機触媒を入れたのち，トリエチルアルミニウムを入れた場含，お よび，同時に両触媒を入れた場合は，反忘の再現性は非常に恶

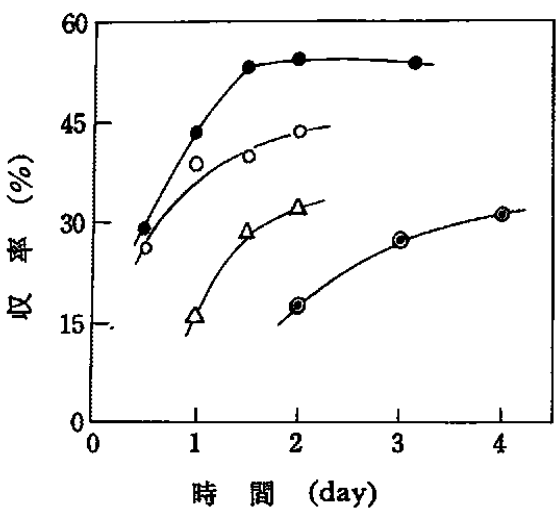

温度 $\left({ }^{\circ} \mathrm{G}\right)-$

: $100,0: 80, \triangle: 60, \bigcirc: 25$

箽合条件

モノマ-/触媒(モル比): 80, 触媒: $\mathrm{BF}_{3} \mathrm{O}\left(\mathrm{C}_{2} \mathrm{H}_{5}\right)_{2}$

因 5 反応温度と反応速度との関係

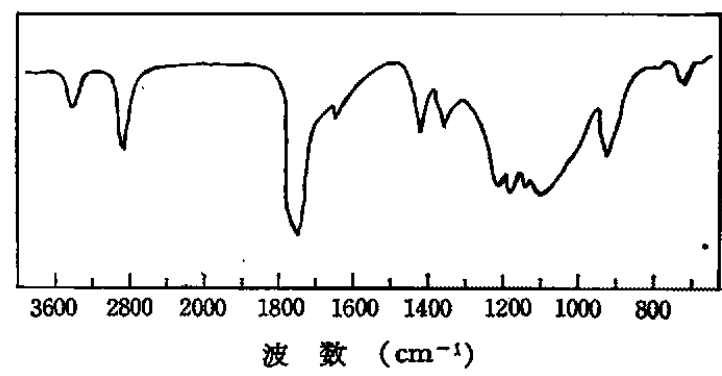

図 6 三フッ化ホウ菜エーテラートによって合成した グリースポりマーの赤外吸収スペクトル

く，とくに後者の場合その傾向がいちじるしい。両触媒を入れた のち少なくとも 10〜12 時間，ドライアイス上に放置して触媒を 活性化したのち，ゆっくり所定の温度まで上げて一定時間反応を 行なうことが望ましい。表 8 に示すように四塩化スズを含む触媒 の重合活性怯，低温で注非常に低く高収率で高重合体を与えない のに対して，三フッ化亦ウ索エーテラートを含む触媒は， $25^{\circ} \mathbf{C}$ の低温で十分な重合活性を示した。また三フッ化ホウ索エーテラ 一トと有機金属として，トリェチルアルミニウムを含む系は，固 体ポリマーと水に不溶性のグリース状ポリマーを与えたが，三フ ッ化ホウ菜エーテラートとシェチル覀鉛を含む二元触媒は，固体 ポリマーをまったく与えなかったことは注目すべきことであろ う(表 9，10)。これは，触媒とポリマーの成長末端においてでき る対イオンの状態が，そノマーが成長末端に近ついてくる条件を きめる大きな要素となっているために生じた結果であると考えら れる。すなわち，電子欠撌原子としてのアルミニウムを含むトリ エチルアルミニウムの立体的, 電子的配位の特異性が，ジェチル 亜鉛よりもモノマーと成長末端との結合をより強く規制すること に基づいていると推測される。一般にトリエチルアルミニウムー 三フッ化ホウ素エーテラート系で得たポリマーの战および炎学 活性度は,トリエチルアルミニウムー四塩化スズ系で得られたす のより大きかった。またポリマーの光学活性度は，グリース状ポ リマーに関するかぎり，有機金属の種類によって影筤されなかっ た(表 9,10$)$ 。

トリェチルアルミニウムー三フッ化ホウ素エーテラート杀によ る垂合反応から、つぎのような結果を得た。 
表 $7 \mathrm{AlEt}_{3}$ を合む二元触禁による重合反忘

反店条件 反忘時間： 4 日, 反応温度: $65^{\circ} \mathrm{C}$, 溶媒: ベンゼン(溶媒/モノマー=1/2(v/v))

\begin{tabular}{|c|c|c|c|c|c|c|}
\hline No. & 媒( ) & $\begin{array}{c}\mathrm{AlEt}_{3} / \\
\text { 無碚化會物 }{ }^{a} \text { ) }\end{array}$ & 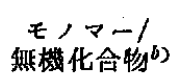 & 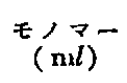 & 触 $\left(\mathrm{C}_{2}\right)^{\text {媒 }}$ & $\begin{array}{c}\text { 全収率 } \\
(\%)\end{array}$ \\
\hline 16 & $\mathrm{AlEt}_{3}-\mathrm{H}_{2} \mathrm{O}$ & 1.5 & 72 & 8.4 & $2 \mathrm{mg}$ & $2 \sim 3$ \\
\hline 17 & $\mathrm{AlEt}_{3}-\mathrm{FeCl}_{3}$ & 1.1 & 72 & 8.4 & $120 \mathrm{mg}$ & $2 \sim 4$ \\
\hline 18 & $\mathrm{AlEt}_{3}-\mathrm{CuO}$ & 1.0 & 72 & 8.4 & $80 \mathrm{mg}$ & $\mathbf{0}$ \\
\hline 19 & $\mathrm{AlEt}_{3}-\mathrm{TiCl}_{3}$ & 1.0 & 72 & 8.4 & $0.15 \mathrm{ml}$ & $2 \sim 3$ \\
\hline 20 & $\mathrm{AlEt}_{3}-\mathrm{TiCl}_{4}$ & 1.0 & 72 & 8.4 & $0.19 \mathrm{ml}$ & 15 \\
\hline 21 & $\mathrm{AlEt}_{3}-\mathrm{KOH}$ & 1.0 & 80 & 9.3 & $0.56 \mathrm{mg}$ & $1 \sim 2$ \\
\hline 22 & $\mathrm{AlEt}_{3}-\mathrm{SnCl}_{4}$ & 1.0 & 80 & 9.3 & $0.26 \mathrm{mg}$ & $10 \sim 14$ \\
\hline 23 & $\mathrm{AlEt}_{3}-\mathrm{Al}\left[\mathrm{OCH}\left(\mathrm{CH}_{3}\right)_{2}\right]_{3}$ & 1.0 & 80 & 9.3 & $204 \mathrm{mg}$ & 0 \\
\hline 24 & $\mathrm{AlEt}_{3}-\mathrm{SnCl}_{2}$ & 1.0 & 80 & 9.3 & $189 \mathrm{mg}$ & 2 \\
\hline 25 & $A \mid E t_{2}-E_{t_{3}} N$ & 1.0 & 80 & 9.3 & $100 \mathrm{mg}$ & 2 \\
\hline 26 & $\mathrm{AlEt}_{3}-\mathrm{SnO}$ & 1.0 & 80 & 9.3 & $134 \mathrm{mg}$ & 1 \\
\hline
\end{tabular}

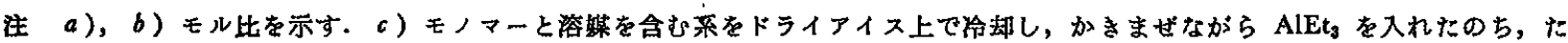

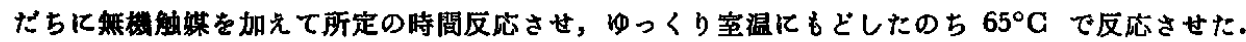

表 8 有機金風を含む二元触媒による重合反応

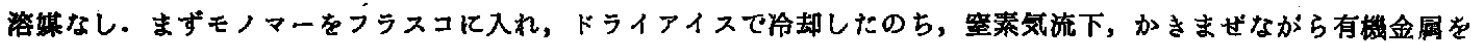

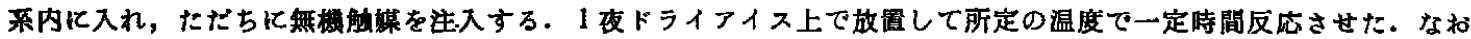
反応収率はもノマーに対する収率である。

\begin{tabular}{|c|c|c|c|c|c|c|}
\hline No. & 触 & 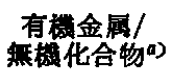 & 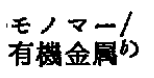 & $\begin{array}{c}\text { 反虑収率( }) \\
(\%)\end{array}$ & $\begin{array}{c}\text { 反応時間 } \\
\text { (day) }\end{array}$ & $\begin{array}{c}\text { 反底沮 } \\
\left({ }^{\circ} \mathrm{C}\right)\end{array}$ \\
\hline 27 & $\mathrm{ZnEt}_{2}-\mathrm{SnCl}_{4}$ & 1.0 & 80 & 10 & 5 & 25 \\
\hline 28 & $\mathrm{AlEt}_{\mathbf{8}}-\mathrm{TiCl}_{4}$ & 1.0 & 100 & $20 \sim 25$ & 4 & 80 \\
\hline 29 & $\mathrm{AlEt}_{\mathbf{8}}-\mathrm{FeCl}_{\mathbf{8}}$ & 1.0 & 76 & 10 & 3 & 80 \\
\hline 30 & $\mathrm{ZnEt}_{2}-\mathrm{SnCl}_{4}$ & 1.0 & 50 & $10 \sim 13$ & 3 & 80 \\
\hline 31 & $\mathrm{AlEt}_{3}-\mathrm{SnCl}_{4}$ & 1.0 & 80 & 35 & 4 & 80 \\
\hline 32 & $\mathrm{AlEt}_{3}-\mathrm{TiCl}_{3}$ & 1.0 & 80 & 35 & 5 & 80 \\
\hline 33 & $\mathrm{AlEt}_{3}-\mathrm{BF}_{3} \mathrm{O}\left(\mathrm{C}_{2} \mathrm{H}_{5}\right)_{2}$ & 1.0 & 80 & 50 & 5 & 25 \\
\hline 34 & $\mathrm{ZnEt}_{2}-\mathrm{BF}_{3} \mathrm{O}\left(\mathrm{C}_{2} \mathrm{HI}_{3}\right)_{2}$ & 1.0 & 80 & 54 & 5 & 25 \\
\hline
\end{tabular}

注 $\quad a) ， b$ ) モル比を示す. c) モノマーに対する収率.

表 9 有倳金剭を含む二元蚛媒による重合反応

反応条件 温度： $80^{\circ} \mathrm{C}$ (ただし No. 9 のみ $\left.110^{\circ} \mathrm{C}\right)$, 時間： 5 日，アンブル重合.

\begin{tabular}{|c|c|c|c|c|c|c|c|c|c|c|c|}
\hline \multirow{2}{*}{ No. } & \multirow{2}{*}{ 触 } & \multirow{2}{*}{$\mathrm{C}_{1} / \mathrm{C}_{2}{ }^{a)}$} & \multirow{2}{*}{$M / G_{1}^{b)}$} & \multirow{2}{*}{ 溶 媒 } & \multirow{2}{*}{$\frac{\text { 収 率 }}{\text { グリース }}$} & $(\%)^{d)}$ & \multicolumn{2}{|c|}{ 比旋光度 $\left({ }^{\circ}\right)^{c)}$} & \multirow{2}{*}{$\left.\eta_{\mathrm{sp}} / c(c=2) f\right)$} & \multicolumn{2}{|c|}{ フラクションe) } \\
\hline & & & & & & 体 & グリース & 固 & & グリース & 固体 \\
\hline 4 & $\mathrm{Et}_{3} \mathrm{Al}-\mathrm{TlCl}_{4}$ & 0.4 & 135 & $\mathrm{C}_{6} \mathrm{H}_{6}$ & 32.3 & し & $\begin{array}{c}-20.2 \\
\left(\mathrm{CH}_{2} \mathrm{Cl}_{2}\right)\end{array}$ & & 0.60 & A 法 & \\
\hline 5 & $\mathrm{Et}_{2} \mathrm{Zn}-\mathrm{TiCl}_{\mathbf{t}}$ & 0.5 & 70 & $\mathrm{C}_{8} \mathrm{H}_{6}$ & 33.0 & ᄂ & $\begin{array}{c}-21.6 \\
\left(\mathrm{CH}_{2} \mathrm{Cl}_{2}\right)\end{array}$ & & & $\mathbf{A}$ & \\
\hline 6 & $\mathrm{Et}_{3} \mathrm{Al}-\mathrm{SnCl} \mathbf{l}_{4}$ & 0.77 & 135 & - & 49.7 & でく少量 & $\begin{array}{l}-22.0 \\
\left(\mathrm{CH}_{2} \mathrm{Cl}_{2}\right)\end{array}$ & $\begin{array}{l}-24.7 \\
(\mathrm{DMF})\end{array}$ & 0.65 & A & B 法 \\
\hline 7 & $\mathrm{Et}_{2} \mathrm{Zn}-\mathrm{SnCl}_{4}$ & 0.9 & 90 & $\mathrm{C}_{6} \mathrm{H}_{6}$ & 56.8 & 0.5 & $\begin{array}{c}-21.0 \\
\left(\mathrm{CH}_{2} \mathrm{Cl}_{2}\right)\end{array}$ & $\begin{array}{l}-23.0 \\
(\mathrm{DMF})\end{array}$ & & A & B \\
\hline 8 & $\mathrm{Et}_{2} \mathrm{Zn}-\mathrm{SnCl}_{4}$ & 0.9 & 90 & - & 60.0 & $\begin{array}{c}\text { C゙ }<\text { 少量 } \\
(0.2)\end{array}$ & $\begin{array}{c}-20.5 \\
\left(\mathrm{CH}_{2} \mathrm{Cl}_{2}\right)\end{array}$ & $\begin{array}{l}-21.5 \\
\left(\mathrm{CH}_{2} \mathrm{Cl}_{2}\right)\end{array}$ & $0.67 f 2$ & B & B \\
\hline 9 & $\mathrm{Et}_{2} \mathrm{Zn}-\mathrm{SnCl}_{4}$ & 0.9 & 90 & - & 40.3 & C゙く少㻎 & $\left(\begin{array}{l}-20.9 \\
\left(\mathrm{CH}_{2} \mathrm{Cl}_{2}\right)\end{array}\right.$ & & 0.59 & B & \\
\hline 10 & $\mathrm{Et}_{2} \mathrm{Zn}-\mathrm{SnCl} \mathbf{4}_{4}$ & 1.0 & 180 & $\mathrm{CH}_{2} \mathrm{Cl}_{2}$ & 53.5 & 0.1 & & $\begin{array}{l}-25.0 \\
(\mathrm{DMF})\end{array}$ & $0.78 f)$ & A & B \\
\hline
\end{tabular}

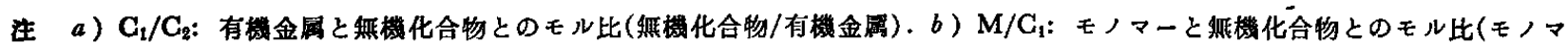

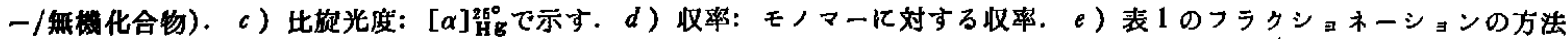
を示す. No.6の方法はまずポリマーを壏化メチレンに溶かし，てれに nーヘプタンを少量加えて国体ポリマーを分别し，口 湤の浴桇を留去して，A法にしたがってポりマーを得る。したがって水に不溶性のグリースポリマーである.No. 8 の方法は

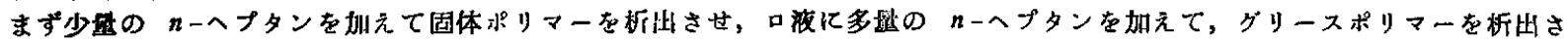
せる方法. f $) \eta_{\mathrm{sp}} / c(c=2)$ ：ベンゼン中の固体ポリマーの值で温度は $40^{\circ} \mathrm{C}$ ，それ以外はグリースポリマーの值を示す.

1) ポリマーの重台度は温度の上界とともに减少した。

2）触媒浱度の上昇とともに反応速度が上界したが，光学活性 度は若干娍少した(表 $11(\mathrm{c}))$ 。
3) トリエテルアルミニウムに対する三フッ化ホウ菜エーテラ ートのモル比が 1 付近でポリマーの収率が最高になり, 光学活性 度も非常に高い固体ポリマーを得ることができる。しかしこのモ 
表 10 有機金風を含む二元能媒による重合反虑

反店条件 温度： $25^{\circ} \mathrm{G}$, 無溶媒(ただしNo. 35 のみベンゼンを使用), 反応操作はすへて夷硂の部のフラスコ重合で 述べた方法にしたがっている(ただし No. 35 のみ $0^{\circ} \sim 4^{\circ} \mathrm{C}$ に命やして行なった)。他はすへて, 表 9 にし たがって記述した。

\begin{tabular}{|c|c|c|c|c|c|c|c|c|c|c|c|c|}
\hline \multirow{2}{*}{ No. } & \multirow{2}{*}{ 触 } & \multirow{2}{*}{$\mathrm{G}_{1} / \mathrm{G}_{2}$} & \multirow{2}{*}{$\mathrm{M} / \mathrm{G}_{1}$} & \multirow{2}{*}{$\begin{array}{l}\text { 時間 } \\
\text { (day) }\end{array}$} & 収率 & $(\%)$ & \multicolumn{2}{|c|}{ 比颙光度 $\left({ }^{\circ}\right)$} & \multicolumn{2}{|c|}{$\eta_{\mathrm{sp}} / c(c=2)$} & \multicolumn{2}{|c|}{ フラクション } \\
\hline & & & & & グリース & 体 & グリース & 体 & クリリース & 固体 & タリース & 固体 \\
\hline 35 & $\mathrm{Et}_{3} \mathrm{Al}-\mathrm{H}_{2} \mathrm{O}$ & 1.0 & 90 & 7 & なし & 0.4 & & & & & & $\mathbf{B i}$ \\
\hline 36 & $\mathrm{Et}_{3} \mathrm{Al}-\mathrm{BF}_{3} \mathrm{O}\left(\mathrm{C}_{2} \mathrm{H}_{5}\right)_{2}$ & 3.2 & 80 & 14 & 45.0 & な し & & & 0.53 & & & \\
\hline 1 & $\mathrm{Et}_{3} \mathrm{Al}-\mathrm{BF}_{3} \mathrm{O}\left(\mathrm{C}_{2} \mathrm{H}_{5}\right)_{2}$ & 5.0 & 150 & 14 & 60.0 & $" 1$ & & & 0.54 & & & \\
\hline 2 & $\mathrm{Et}_{3} \mathrm{Al}-\mathrm{BF}_{3} \mathrm{O}\left(\mathrm{C}_{2} \mathrm{H}_{5}\right)_{2}$ & 3.7 & 230 & 14 & 21.9 & こく少在 & $\begin{array}{c}-23.0 \\
\left(\mathrm{CH}_{2} \mathrm{Cl}_{2}\right)\end{array}$ & & & & A 法 & $\mathbf{A}$ \\
\hline 3 & $\mathrm{Et}_{3} \mathrm{Al}-\mathrm{BF}_{3} \mathrm{O}\left(\mathrm{C}_{2} \mathrm{H}_{5}\right)_{2}$ & 0.84 & 270 & 14 & $26: 4$ & 0.6 & $\begin{array}{c}-31.5 \\
\left(\mathrm{CH}_{2} \mathrm{Cl}_{2}\right)\end{array}$ & $\begin{array}{c}-30.1 \\
\left(\mathrm{CH}_{2} \mathrm{Cl}_{2}\right)\end{array}$ & 0.89 & & B & $\mathbf{B}$ \\
\hline 11 & $\mathrm{Et}_{2} \mathrm{Zn}-\mathrm{BF}_{3} \mathrm{O}\left(\mathrm{C}_{2} \mathrm{H}_{5}\right)_{2}$ & 2.2 & 126 & 20 & 43.3 & なし & $\begin{array}{c}-22.0 \\
\left(\mathrm{CH}_{2} \mathrm{Cl}_{2}\right)\end{array}$ & & 0.84 & & $\mathbf{A}$ & \\
\hline 12 & $\mathrm{Et}_{2} \mathrm{Zn}-\mathrm{SnCl}_{4} / \mathrm{TiCl}_{4}$ & 1.2 & 180 & 25 & ごく少量 & $"$ & & & & & & \\
\hline 13 & $\mathrm{Et}_{2} \mathrm{Zn}-\mathrm{BF}_{3} \mathrm{O}\left(\mathrm{C}_{2} \mathrm{H}_{5}\right)_{2}$ & 1.2 & 190 & 20 & 55.6 & " & $\begin{array}{l}-32.7 \\
(\mathrm{DMF})\end{array}$ & & 0.98 & & $\mathbf{A}$ & \\
\hline 14 & $\mathrm{Et}_{2} \mathrm{Zn}-\mathrm{BF}_{3} \mathrm{O}\left(\mathrm{C}_{2} \mathrm{H}_{3}\right)_{2}$ & 0.8 & 180 & 20 & 40.3 & " & $\begin{array}{l}-35.0 \\
(\mathrm{DMF})\end{array}$ & & 0.98 & & $\mathbf{A}$ & \\
\hline
\end{tabular}

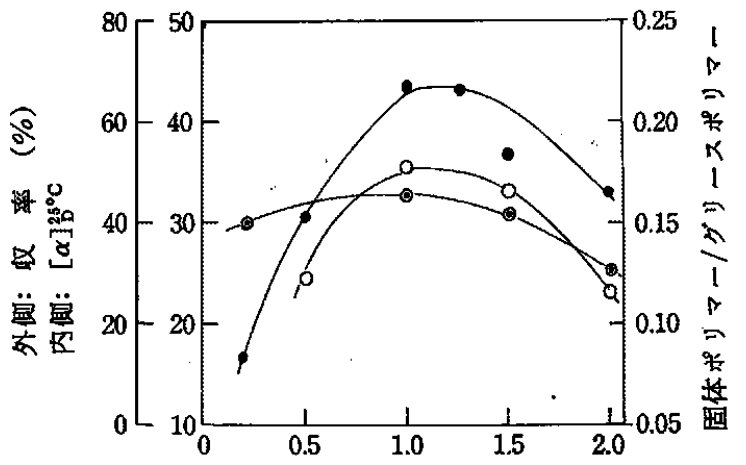

$\mathrm{Et}_{3} \mathrm{Al} / \mathrm{BF}_{3} \mathrm{O}\left(\mathrm{C}_{2} \mathrm{H}_{5}\right)_{2}$ (モル比)

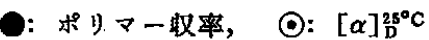

O：固体ポりマー/グリースポリマー (w/w)

图 7 ・リエチルアルミ゙ウムと三フッ化木ウ素エーテ ラートとの比が墨合反応に打よはす影響

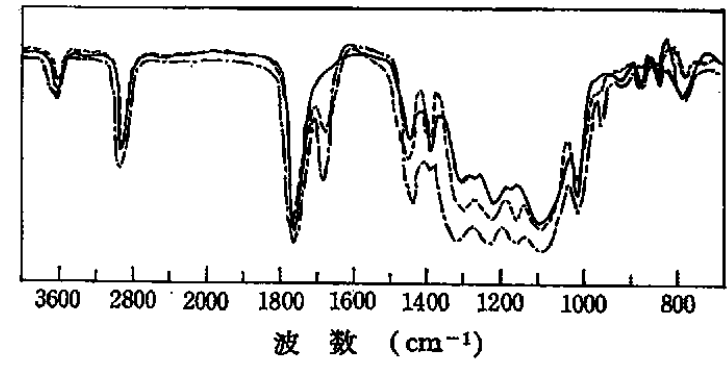

反店時間(day)

$$
\text { —: 2, ---: 14, --_: } 25
$$

図 8 No. 3 の条件で合成したポリマーの赤外吸取スペクトル

ル比が 2.0 以上になると反応収率は極度に低下し，逆に 0.5 以 下の範囲では，固体ポリマーをほとんど得ることはできない(表 11，图 7)。同時にポりマーの光学活性度が低下し，その傾向は シフッ化市素エーテラートが減るにつれていちじるしくなっ た。トリエチルアルミニウムと三フッ化ホウ案エーテラートある いはジエチル唚鉛と三フッ化ホウ素エーテラートで得たグリース 状ポリマーの偏光赤外吸取スペクトル老测定したところ，図 10 , 11 に示すようにメチル基，エステル基の忣収位置に，非常にわ

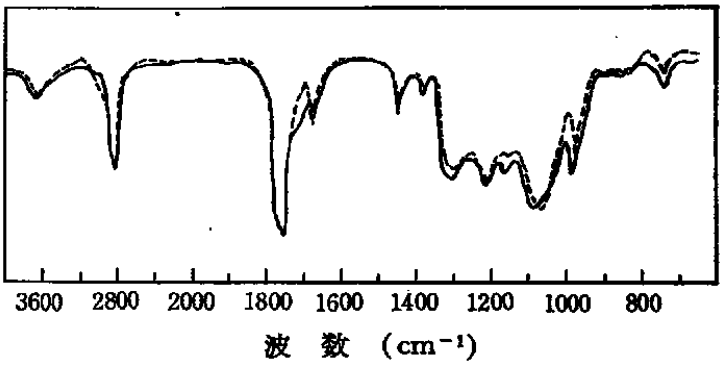

一：No. 3 で合成したグリースポリマー

----: No. 3 で合成した固体ポリマー

図 9 トリエチルアルミニウムと三フッ化ホウ秦エーテ ラート系を触として合成したグリースポりマー と固体ポリマーとの赤外吸収スペクトル

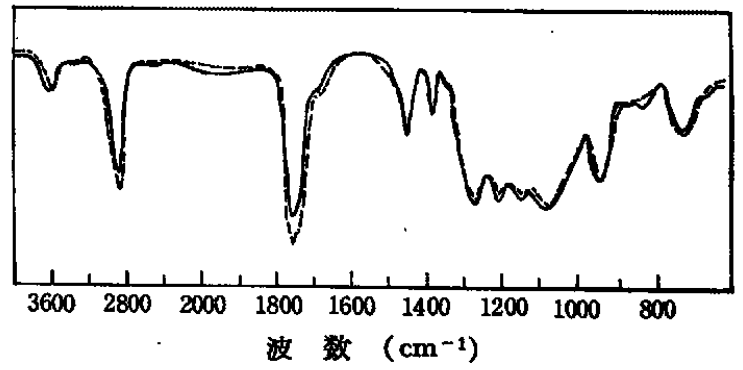

- Parallel, ----: Perpendicular

圀 10 No. 11 のグリース状ポりマーの 漏光赤外吸収スペクトル

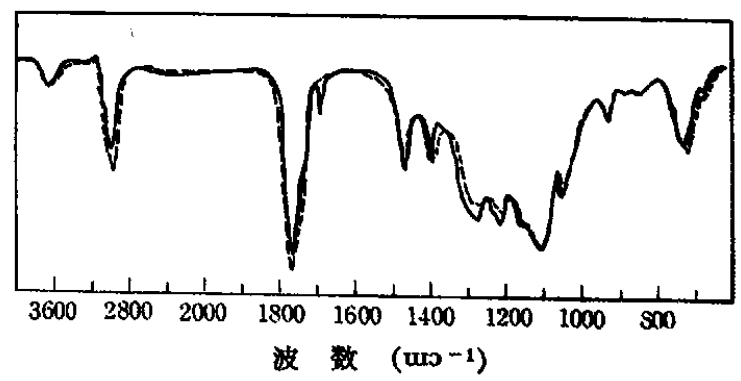

- : Parallel, ----: Perpendicular

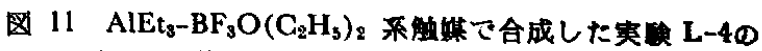
グリース状ボリマーD偏光赤外㽖収スペクトル 
表 11 (a) $\mathrm{AlEt}_{3}$ と $\mathrm{BF}_{3} \mathrm{O}\left(\mathrm{C}_{2} \mathrm{H}_{5}\right)_{2}$ のモル比の重合反応飞打よぼす影響

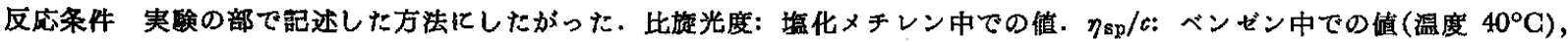
時間: 14 日, 温度: $25^{\circ} \mathrm{G}$, 溶媒: なし.

\begin{tabular}{|c|c|c|c|c|c|c|c|c|}
\hline \multirow{2}{*}{ No. } & \multirow{2}{*}{$\begin{array}{c}\mathrm{BF}_{3} \mathrm{O}\left(\mathrm{C}_{2} \mathrm{H}_{5}\right)_{2} / \mathrm{AlEt}_{3} \\
(\mathrm{~mol} \mathrm{It})\end{array}$} & \multirow{2}{*}{ 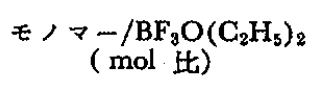 } & \multicolumn{2}{|c|}{ 金収率 $(\%)$} & \multicolumn{2}{|c|}{ 比旋光度 $[\alpha]_{5}^{25^{\circ}}{ }^{\circ} \mathrm{c}\left({ }^{\circ}\right)$} & \multicolumn{2}{|c|}{$\eta_{\mathrm{sp}} / c(c=2)$} \\
\hline & & & グリース & 固 & グリース & 固 & グリース & 固 \\
\hline $\mathrm{L}-2$ & 3.7 & 230 & 21.9 & ごく少量 & -23.0 & & 0.95 & \\
\hline L-3 & 2.0 & 232 & 40.2 & 5.2 & -25.0 & & 1.04 & 1.18 \\
\hline L-4 & 1.0 & 230 & 57.3 & 10.2 & -32.4 & -36.9 & 1.16 & 1.20 \\
\hline $\mathrm{L}-7$ & 0.2 & 230 & 10.4 & なし & -30.0 & & & \\
\hline L-8 & 0.94 & 270 & 45.3 & 10.4 & -34.5 & -36.8 & 1.10 & 1.14 \\
\hline
\end{tabular}

表 11(b) $\mathrm{AlEt}_{3}$ と $\mathrm{SnCl}_{4}$ のル比の重合反応に和よばす影郎

反応条件 反応温度： $80^{\circ} \mathrm{C}$, 反応時間： 5 日, 溶媒: 無溶媒, 此旋光度：塩化メチレン中での値, $\eta_{\text {sp }} / c$ : ペンゼン中での值 (混度 $40^{\circ} \mathrm{C}$ )

\begin{tabular}{|c|c|c|c|c|c|c|c|c|}
\hline \multirow{2}{*}{ No. } & \multirow{2}{*}{$\begin{array}{c}\mathrm{SnCl}_{4} / \mathrm{AlEt}_{8} \\
(\mathrm{~mol} \text { 比) }\end{array}$} & \multirow{2}{*}{ 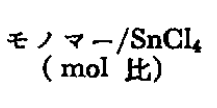 } & \multirow{2}{*}{$\frac{\text { 全取率 }}{\text { グシース }}$} & $(\%)$ & \multicolumn{2}{|c|}{ 比旋光度 $[\alpha]_{D}^{25^{\circ}} \mathrm{C}\left({ }^{\circ}\right)$} & \multicolumn{2}{|c|}{$\eta_{\mathrm{sp}} / c(c=2)$} \\
\hline & & & & 体 & グリース & 固 & グリース & 固 \\
\hline S -1 & 3.7 & 230 & 28.3 & と゚く少量 & -20.0 & & 0.25 & \\
\hline S -2 & 2.0 & 232 & 40.5 & 0.3 & -21.5 & & 0.61 & \\
\hline$S-3$ & 1.0 & 230 & 42.0 & 0.8 & -25.0 & -24.4 & 0.70 & 0.72 \\
\hline$S-4$ & 0.2 & 230 & 8.5 & どく少量 & -23.4 & & 0.65 & \\
\hline S-5 & 0.94 & 270 & 41.0 & 0.8 & -27.4 & -28.9 & 0.65 & 0.74 \\
\hline
\end{tabular}

表 11(c) $\mathrm{AlEt}_{3}$ と $\mathrm{BF}_{3} \mathrm{O}\left(\mathrm{C}_{2} \mathrm{H}_{5}\right)_{2}$ かららる触媒の電合反応 $\mathrm{AlEt}_{3} / \mathrm{BF}_{3} \mathrm{O}\left(\mathrm{C}_{2} \mathrm{H}_{5}\right)_{2}(\mathrm{~mol}$ 比 $)=1.0$, 全収率: モノマーに対するポリマーの収率, $[\alpha]_{\mathrm{D}}^{25^{\circ} \mathrm{C}}$ : 㙁化メテレン中の值, $\eta_{\mathrm{sp}} / c$ : ベンゼン中の値.

\begin{tabular}{|c|c|c|c|c|c|c|}
\hline No. & 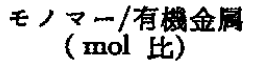 & ${ }^{\left({ }^{\circ} \mathrm{G}\right)}$ & $\begin{array}{l}\text { 時 閐 } \\
\text { (day) }\end{array}$ & $\begin{array}{l}\text { 全収率 } \\
(\%)\end{array}$ & 比旋光度 $[\alpha]^{25^{\circ}} \mathrm{C}$ & $\eta_{\mathrm{sp}} / c(c=2) 40^{\circ} \mathrm{G}$ \\
\hline M-1 & 230 & 25 & 14 & 67.5 & -34.5 & 1.16 \\
\hline M-2 & 230 & 50 & 14 & 60.8 & -28.7 & 1.03 \\
\hline $\mathbf{M}-3$ & 230 & 80 & 14 & 63.0 & -26.5 & 1.00 \\
\hline M-4 & 230 & 100 & 14 & 61.6 & -24.0 & 0.70 \\
\hline $\mathrm{N}-5$ & 50 & 25 & 5 & 56.0 & -28.0 & \\
\hline $\mathrm{N}-6$ & 80 & 25 & 5 & 50.0 & -28.4 & \\
\hline $\mathrm{N}-7$ & 120 & 25 & 5 & 35.0 & -28.9 & \\
\hline $\mathrm{N}-10$ & 180 & 25 & 5 & 32.5 & -30.9 & \\
\hline$N-15$ & 230 & 25 & 5 & 20.8 & -35.0 & \\
\hline
\end{tabular}

表 $11(\mathrm{~d}) \quad \mathrm{ZnEt}_{2}-\mathrm{BF}_{3} \mathrm{O}\left(\mathrm{C}_{2} \mathrm{H}_{5}\right)_{2}$ 系触媒化上万重合反灾

反応条件 温度: $25^{\circ} \mathrm{C}$, 時間: 14 日, 比旋光度: $[\alpha]_{\mathrm{H}}^{25^{\circ} \mathrm{C}}$ (塩化メチレン中) その他の表示はすべて前表にしたがった。

\begin{tabular}{|c|c|c|c|c|c|c|c|c|}
\hline \multirow{2}{*}{ No. } & \multirow{2}{*}{$\mathrm{BF}_{8} \mathrm{O}\left(\mathrm{C}_{2} \mathrm{H}_{5}\right)_{2} / \mathrm{ZnEt}_{2}$} & \multirow{2}{*}{ 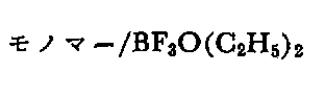 } & \multicolumn{2}{|c|}{ 全収率 （\%) } & \multicolumn{2}{|c|}{ 此旋光度 $\left(^{\circ}\right)$} & \multicolumn{2}{|c|}{$\eta_{\mathrm{sp}} / c(c=2)$} \\
\hline & & & グリース & 固 体 & グリース & 固 体 & グリース & 固 \\
\hline $\mathbf{P}-1$ & 5.0 & 230 & 48.0 & なし & -20.0 & & 0.69 & \\
\hline $\mathbf{P}-2$ & 3.7 & 232 & 40.0 & " & -20.5 & & 0.72 & \\
\hline $\mathbf{P}-\mathbf{3}$ & 2.0 & 230 & 50.6 & " & -25.5 & & 0.97 & \\
\hline $\mathbf{P}-4$ & 1.0 & 230 & 50.9 & " & -29.8 & & 0.98 & \\
\hline$P \sim 5$ & 0.2 & 230 & 9.5 & " & -30.2 & & 1.05 & \\
\hline $\mathbf{P}-6$ & 0.94 & 270 & 50.1 & " & -28.5 & & 0.95 & \\
\hline
\end{tabular}

表 11 (e ) $\mathrm{ZnEt}_{2}-\mathrm{SnCl}_{4}$ 系伤媒化よ万重合反応

反店条件 温度: $80^{\circ} \mathrm{C}$, 時闎: 3 日, 溶媒: 無浴媒, 比旋光度: $[\alpha]_{\mathrm{H}}^{25^{\circ}}\left(\mathrm{CH}_{2} \mathrm{Cl}_{2}\right.$ 中)

\begin{tabular}{|c|c|c|c|c|c|c|c|c|}
\hline \multirow{2}{*}{ No. } & \multirow{2}{*}{$\mathrm{BF}_{3} \mathrm{O}\left(\mathrm{C}_{2} \mathrm{H}_{5}\right)_{2} / \mathrm{SnCl}_{4}$} & \multirow{2}{*}{$乇 / マ-/ \mathrm{BF}_{8} \mathrm{O}\left(\mathrm{C}_{2} \mathrm{H}_{5}\right)_{2}$} & \multicolumn{2}{|c|}{ 全収率 $(\%)$} & \multicolumn{2}{|c|}{ 比旋光度 $\left({ }^{\circ}\right)$} & \multicolumn{2}{|c|}{$\eta_{\mathrm{sp}} / c(c=2)$} \\
\hline & & & グリース & 固 体 & グリース & 固 体 & グリース & 圈 体 \\
\hline Q-1 & 3.7 & 230 & 20.5 & なし & -19.8 & & 0.26 & \\
\hline$\widehat{Q}-2$ & 2.0 & 232 & 29.0 & " & -19.7 & & 0.57 & \\
\hline Q-3 & 1.0 & 230 & 32.5 & 0.5 & -20.0 & -21.8 & 0.60 & 0.66 \\
\hline$Q-4$ & 0.2 & 230 & 5.0 & 少 量 & -24.0 & & 0.60 & \\
\hline Q-5 & 0.94 & 270 & 30.7 & 0.6 & -21.2 & -22.3 & 0.69 & 0.71 \\
\hline
\end{tabular}




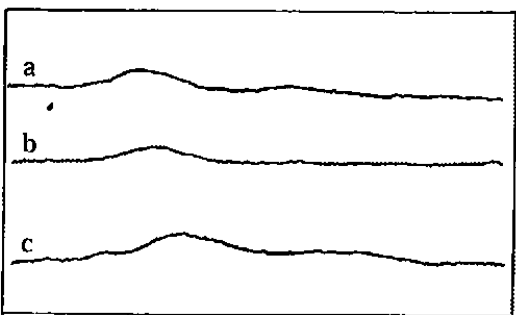

$2 \theta$

a : $\mathrm{AlEt}_{3}-\mathrm{BF}_{3} \mathrm{O}\left(\mathrm{C}_{2} \mathrm{H}_{5}\right)_{2}$ で合成した固体ポリマー

(No. $3 の も の)$

b : $\mathrm{ZnEt}_{2}-\mathrm{BF}_{3} \mathrm{O}\left(\mathrm{C}_{2} \mathrm{H}_{5}\right)_{2}$ で合成したグリースポリマー

(No. 13 のもの)

c：bのポりマーKオリエンテーションをかけてつくっ たサンプルのスペクトル

図12 ポリー( $\beta$-MGAM)のX線スペクトル

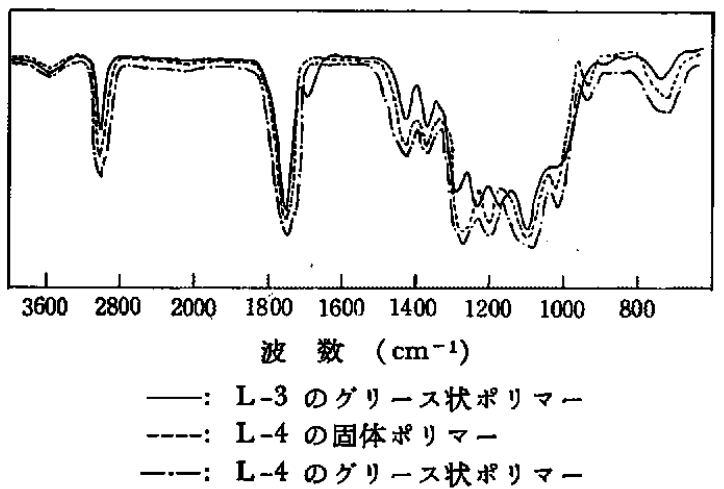

図13 表 11 (a)のポリ-( $\beta$-MGAM)の赤外吸収スペクトル

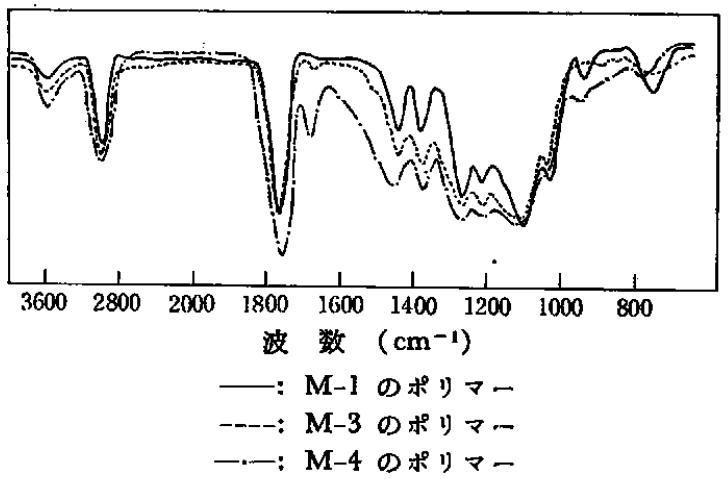

图 14 表 $11(\mathrm{c})$ ポリー( $\beta$-MGAM)の赤外吸収スペクトル

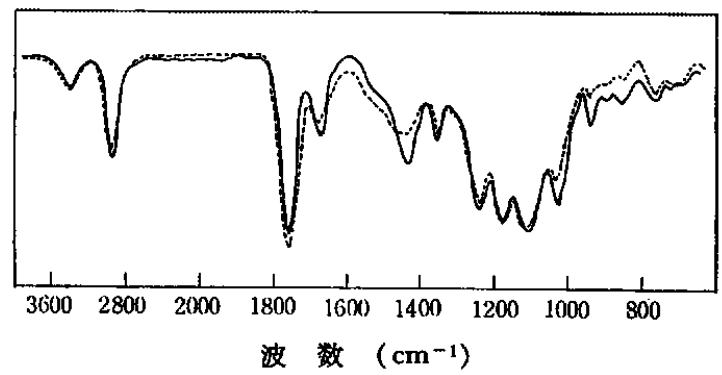

：-3のグリース状ポリマーの赤外吸収スペクトル -一：－－2のグリース状ポリマーの赤外吸収スペクトル 図15 S系のグリース状ポリマーの赤外吸収スペクトル
ずかではあるが二色性が認められたが，X 線スペクトルによれ ば，いずれも非晶性であり構造上とくにいちじるしい特長は認め られなかった。

\section{3 トリエチルアルミニウムー水系触菒}

水で処理したトリエチルアルミニウムの重合活性については, 古川，三枝らによって報告されている。著者らもこの触媒を使用 して重合反応を試みた。表 12 に示すように得られたポリマーは グリース部分と少量の白色口ウ状の固体部分からなっていた。固 体ポリマーの赤外㠷取スペクトルを図 16 に示した。この赤外吸 収スペクトルは室温で得られたポリマーであるが, $1650 \mathrm{~cm}^{-1}$ 付 近の二重結合の吸取スペクトルが非常に小さいのが特徽である。

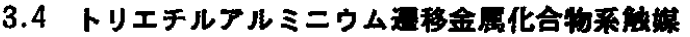

邉移金属化合物をトリエチルアルミニウムで前処理して得られ た触媒がプロピレンオキシドに対して高い箽合活性を示し，結晶 性重合体を与えることが報告されたがも， $\beta$-MGAM に対してど のような作用を示すか検討した。僄移金属化合物として，鉄アを チルアセトネートとコバルトアセチルアセトネートとを使用し た実験結果を衰 13 に示した。重合方法は一部をのぞいて神原ら の方法沈したがった。

\section{表 $12 \mathrm{AlEt}_{3} / \mathrm{H}_{2} \mathrm{O}$ 系触媒(}

反応条件 温度： $55^{\circ} \mathrm{C}$, 時間： 5 日間, 溶媒: 無溶媒,

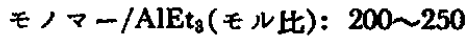

\begin{tabular}{|c|c|c|c|c|c|}
\hline \multirow{2}{*}{$\mathrm{AlEt}_{3} / \mathrm{H}_{2} \mathrm{O}$} & \multirow{2}{*}{$\frac{\text { 収 率 }}{\text { グシース }}$} & \multirow{2}{*}{$\frac{(\%)}{\text { 固体 }}$} & \multicolumn{2}{|c|}{$\eta_{\mathrm{sp}} / c(c=2)^{b)}$} & \multirow{2}{*}{$\begin{array}{c}\text { 比旋光度( } \\
\left({ }^{\circ}\right)\end{array}$} \\
\hline & & & グリース & 固体 & \\
\hline 0.2 & 15.0 & なし & 0.75 & & \\
\hline 0.5 & 15.0 & $2 \sim 3$ & 0.78 & 0.91 & -30.5 \\
\hline 1.0 & 12.0 & 7.3 & 1.01 & 1.10 & -32.6 \\
\hline 2.0 & 10.5 & 5.0 & 0.76 & & $-31.5^{* *}$ \\
\hline 5.0 & 9.3 & 5.0 & & & \\
\hline $0.2^{*}$ & 5.2 & なし & & & \\
\hline $1.0^{*}$ & 13.8 & $2 \sim 4$ & 0.60 & 0.85 & -30.4 \\
\hline $5.0^{*}$ & 9.6 & 3 & & & \\
\hline
\end{tabular}

注 a）実験の部で調製した触媒. b) $40^{\circ} \mathrm{C}$ の值(ペンゼン). c）㙁化メチレン中での值を示す $\left([\alpha]^{25^{\circ}}\right)$. ポリマーの分 別はＢ法(表り)にしたがった。*以外のるのは口液。*の ものは沈段物をそれそれ触媒としていろ. 比旋光度の值は， 固体ポリマーのちの(ただし**用のしのはグリース状ポり マ-の值).

表 13 要移金属化合物を合む触媒によろ至合反応 反応条件，温度： $50^{\circ} \mathrm{C}$ (ただし，F-5 のみ $60^{\circ} \mathrm{C}$ )， 溶媒：なし.

\begin{tabular}{|c|c|c|c|c|c|}
\hline No. & $\begin{array}{c}\mathrm{AlEt}_{3} / \\
\mathrm{Co}(\mathrm{acac})_{8}\end{array}$ & $\begin{array}{l}\text { 時間 } \\
\text { (day) }\end{array}$ & $\begin{array}{l}\text { 全収率 } \\
(\%)\end{array}$ & $\begin{array}{r}\text { 固体ポり } \\
(\%)\end{array}$ & $\begin{array}{c}\nabla-b]^{25}{ }^{c}(\alpha) \\
\text { (固体) }\end{array}$ \\
\hline$F-1$ & 1.2 & 5 & 22.4 & 1.3 & 30.0 \\
\hline F -2 & 2.5 & 3 & 31.8 & 20.5 & 31.8 \\
\hline F -3 & 3.5 & 3 & 28.9 & 15.3 & \\
\hline F -4 & 4.8 & 2 & 28.3 & 6.3 & \\
\hline F -5 & 5.3 & 3 & 23.8 & & $29.8^{*}$ \\
\hline F -6 & 2.3 & 3 & 20.0 & 10.3 & 90.5 \\
\hline$F-8$ & 3.0 & 3 & 20.5 & & \\
\hline $\mathbf{F}-10$ & 4.2 & 3 & 23.8 & & \\
\hline$F-11$ & 4.8 & 4 & & & \\
\hline
\end{tabular}

注 a) 比旋光度：塩化メチレン中での值で固体ポりマーの比 旋光度を示す. F-6〜 F-11 は Fe(acac)s Co(acac)s

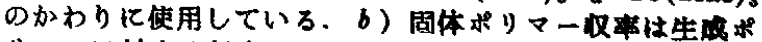

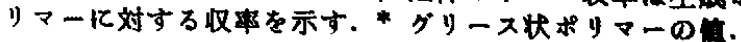

9) 神原, 踑野, 工化, 66, 1126(1963). 
コバルトトリアセチルアセトネートに刘して，2〜4 倍モル是 のトリエチルアルミニウムを含む系で固体ポリマーの収华が最语 になり，しかるポリマーの全取率が非常に商くなっていることが わかる。固体ポリマーは，水，n一ヘプタンに不溶性，ベンゼンに 難㳊性の光学活性ポリマーであった。粘度，光学活性度はいずれ む他の固体ポリマーに此较してほとんど同じで，X 線スペクト ル，赤外吸収スペクトルの結果によれ代とくにいちじるしい特長 は認められなかった。

ここで注目すべきことは触媒調整の仕方によって，触媒活性が 变化するととである。まず罯移金属をべンゼン，トルエンのよう な芳香族化合物に溶かしたものでは，トリエテルアルミニウムを

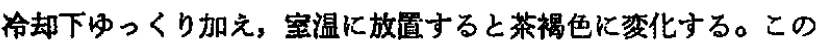
あのはすでに 重合活性をもっているがその程度は低い。これを $50^{\circ} \sim 70^{\circ} \mathrm{C}$ に温度を上げると黑褐色の不透明な液となる。この

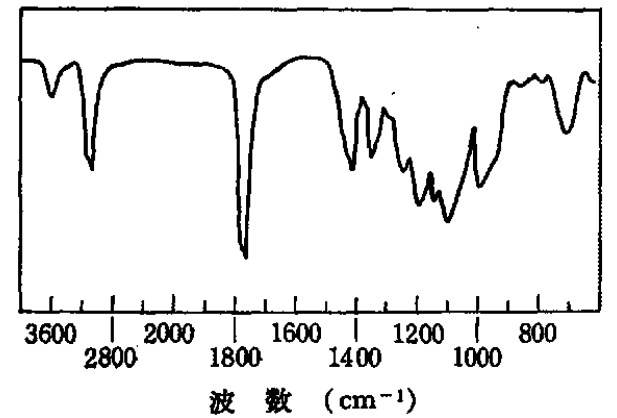

图 $16 \mathrm{AlEt}_{3}-\mathrm{H}_{2} \mathrm{O}$ 系能媒で合成したポリー $(\beta-\mathrm{MGAM})$ の赤外略収スペクトル

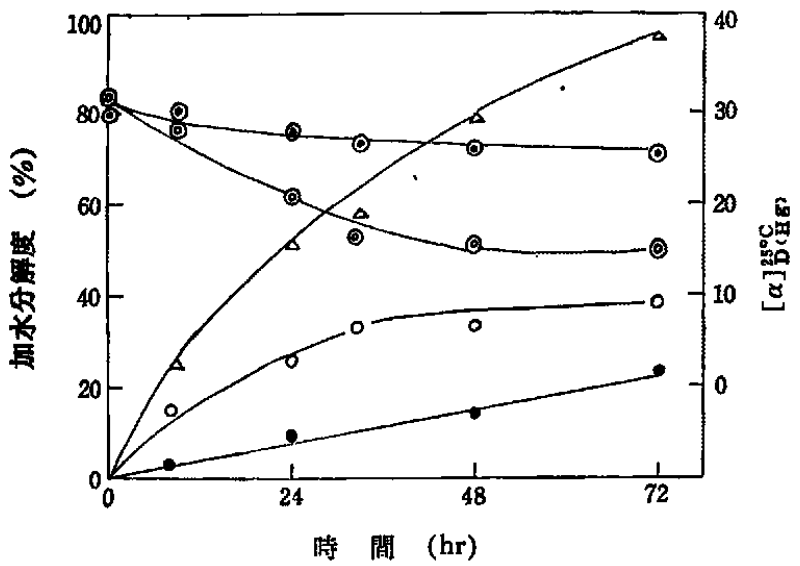

加水分解度二使用にた NaOH のモル数

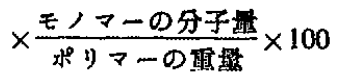

加水分解䊝作： $0^{\circ} \sim 4^{\circ} \mathrm{C} ， 2 \mathrm{~N} \mathrm{HCl}$ で加水分解したのち， DMF以下の谒合，まず有機溶媒を減圧留去し，有

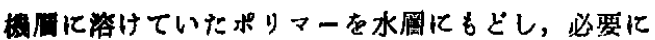
芯して，DMF加えて，均一圆にしたのち，0.05 N NaOH で中和した.

比施光度：ポリマーを水汇浴汃し，その水と同㫣のDM Fを如えた溶液の比旋光度の值を示した。

$\triangle:$ DMF 溶楪中でのポりマーの加水分解

O: $\mathrm{CH}_{2} \mathrm{Cl}_{2}$ 溶婪中でのポリマーの永分解

: 水中でのポリマーの加水分解

○: $\mathrm{CH}_{2} \mathrm{Cl}_{2}$ 中で如水分解したポリマーの比旋光度

O：DMF中で如水分解したポリマーの比旗光度

因 17 ポリマーの扣水分解度と比旅光度との成俰

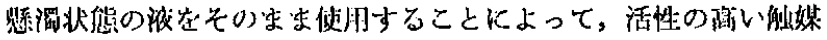
を得むことができう。

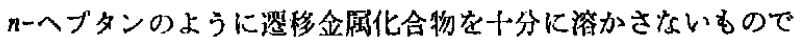

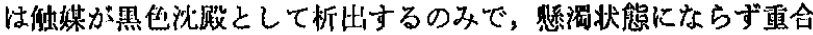
反応を效果的に行なうには，かきまぜながら反応を行ならことが 必要である。トリエチルアルミニウムで茼製した液を口過して得 た沈段部分と上澄部分怯ともに重合活性が低く，とくに液愿は ほとんど重合反応を行なわなかった。以上のことから，图体重合 体を得るためにはトリエチルアルぞウムが邆移金属を再合反応 它行なわせるのに十分必耍な状態まで還元することが必要であ り，しかる触媒活性は液相と凰相との再部分が其存したエマルシ

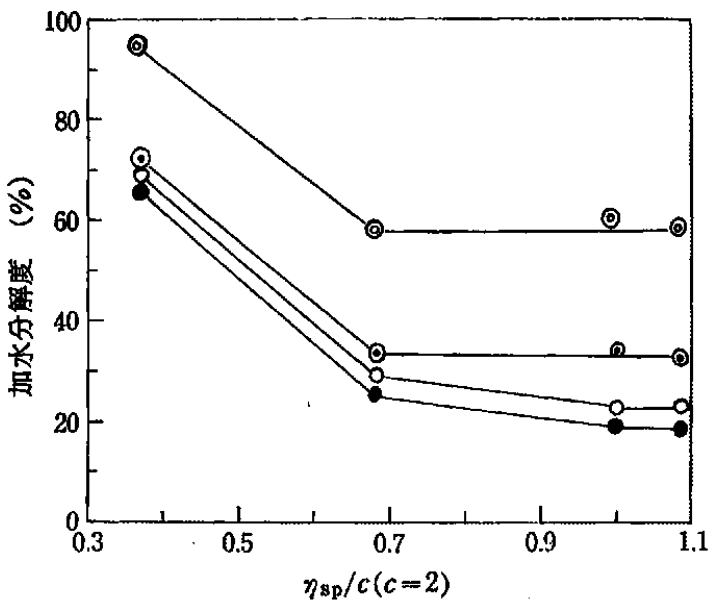

实駖损作は図 14 で述べだ方法にしたがって行なった。 ただし，加水分侽㭙間 24 洔間. 反応㳑度空温での絬果を示す。

O: $\mathrm{C}_{6} \mathrm{H}_{6}$ 中での加水分解

O: $\mathrm{CCl}_{4}$ 中での加水分解

(-): $\mathrm{CH}_{2} \mathrm{Cl}_{2}$ 中での扣水分解

(O): DMF 中ての加水分解

図 18 ポりマーa)の粘度と如水分解速度との関係

注 a) こてで便用したポリマーはグリース状ポりマーである。

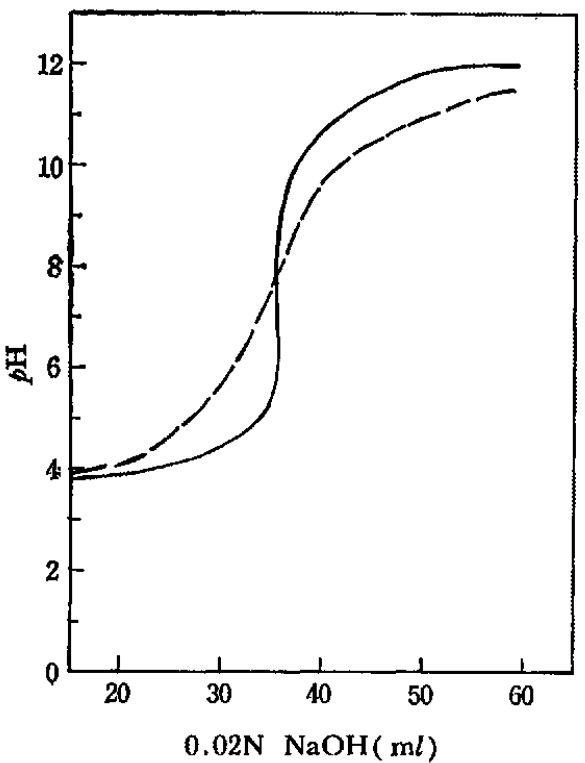

一: $\mathrm{BF}_{3} \mathrm{O}\left(\mathrm{C}_{2} \mathrm{H}_{5}\right)_{2}$ で得たグリース状ポリマーの滴定县線

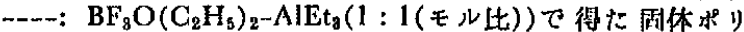
マ - $\left(\eta_{\mathrm{sp}} / c(c=2)=1.2\right)$ の滴定曲線

四 19 新水分解して得られたポリー( $\beta$ グリシド酸)の被定明線 
:ン状態でもっとも強く裴われ\%と考えられる。

トリメチルアルミニウムの䍿移金放化合物に対する作用は，溶 媒によって買なっている。たとえば，アセトン，エーテルのよう な含酸素溶媒中では，コバルトアセチルアセトネートは 4〜5 倍

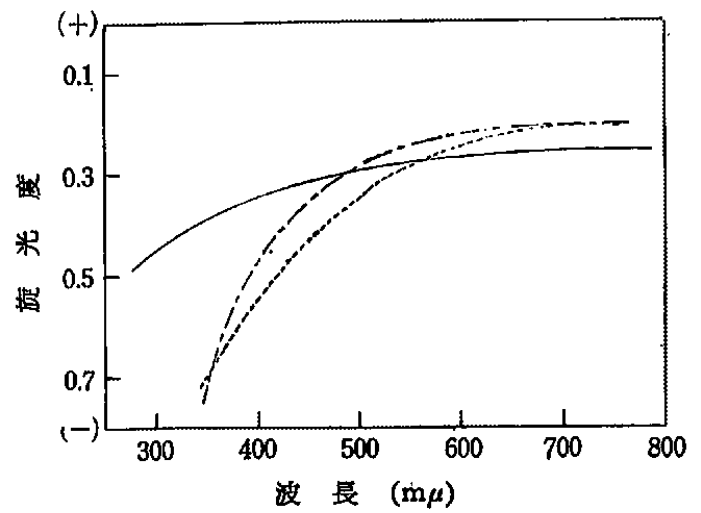

一・—: ポリー( $\beta$-MGAM)の ORD 曲線(No. 11 のポリマー)

----: ポリ-( $\beta$-MGAM)の ORD 曲線(No. 3 のポリマー)

—: ポリ $-(\beta-\mathrm{MGA}) の$ ORD 曲線(No. 3 のポリマーから

馀望したもので抈水分解度 $27.9 \%$ のもの)

図 20 ポリー $(\beta-M G A M)$ 扰よびポリ $-(\beta-M G A)^{a)}$ の ORD 曲綄

注 $a)$ ポリー( $\beta$-MGAM)を机水分解して得られた.ポリエーテ ルの略.

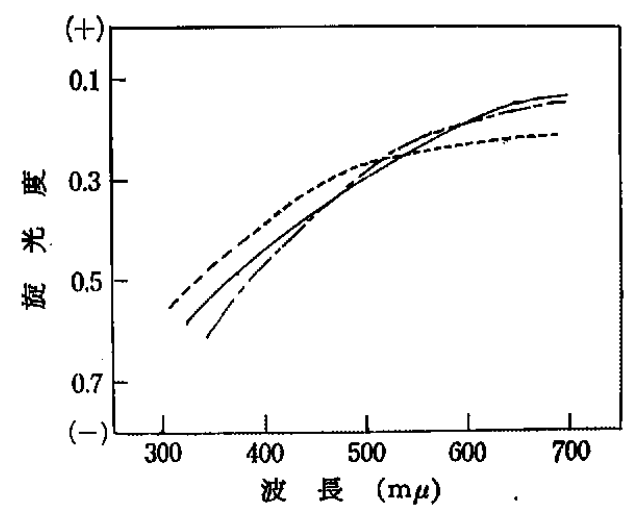

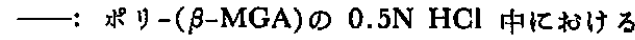
ORD 旺綩(沜度 $5 \%$ )

----: ポリー( $\beta$-MGA)の $0.5 \mathrm{~N} \mathrm{NaOH}$ 中に打ける ORD 抽綄(湍度 $5 \%$ )

-・D: ポリー $(\beta-\mathrm{MGA})$ の水中に打ける ORD曲線 (滥度 $5 \%$ )

図 21 ポリー( $\beta$-MGA)の ORD 証線

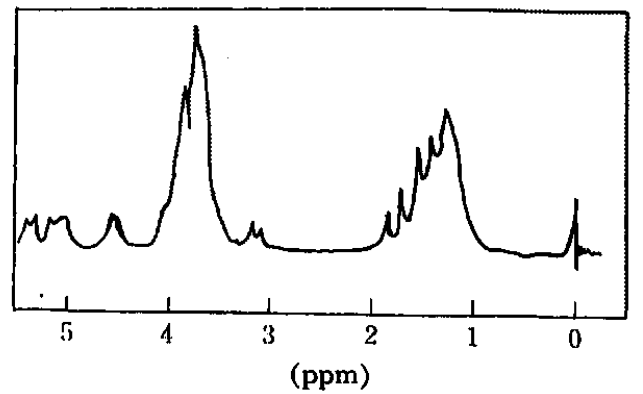

図 $22 \quad \mathrm{BF}_{3} \mathrm{O}\left(\mathrm{C}_{2} \mathrm{H}_{6}\right)_{2}$ 在触媒として合成したポリー $(\beta-$ MGAM)の NMR スペクトル(ベンゼン㩁没中のか゚ リマーの NMR スペクトル)
モル量のトリェチルアルミニウムによってを容易に運元されず， シクロヘキサノン中では，15２0 分， $70^{\circ} \mathrm{C}$ に放晴しても淮は 黑紫色に変色するが不透明にならず重合活性は非常に低かった。 一方ピリシン, アニリン, DMF の含窒菜溶媒中では, コバルト アセチルアセトネートはトリエチルアルミニウムによって比儌的 容易に還元されるが，液は茶褐色透明で重合活性は低かった。

\section{5 ポリー( $\beta$-MGAM)のエステル望の加水分的}

このポリエーテルは，酸性あるいはアルカリ性溶泎に対して不 安定であった。たとえば 2〜3N 塩酸中で $50^{\circ} \sim 60^{\circ} \mathrm{C} て ゙ 24$ 時 間以上加水分解すると主鎖の分解が同時に起り，ポリマーの粘度 が極度に 低下した。すっとも効果的な 加水分解注， $30^{\circ} \sim 40^{\circ} \mathrm{C}$ で 2N 塭酸中で 24 時間反応させることであり,この反応では ポリマーの主鎖の分解が認められないようである。

加水分解速度は吅極性溶媒より極性溶媒の方がはやかった。と れは溶媒に溶けたポリマーの conformation の違いに基つくもの であろう。この結果を図 18 に示した。また極性溶媒のなかで 水に可溶性の DMF 中では加水分解速度ははやく，ポリマーは ほとえど完全に加水分解された(図 17，18)。

加水分解されたポリマーは白色不透明の無定形ポリマーで，と のポリマーは水に対して強い親和性をもち, 水に不浴性のポリマ 一少ら得られた加水分解ポリマーは水に可溶性になった。

加水分的されたボリマーの光学活性および粘度は, 加水分解し ないむのより小さかった。滴定曲線は重合度の堌加とともに渵広 くなり笚純曲線を示した。㳬光分散曲線る単純曲線であり，ポリ マー溶液の $p \mathrm{H}$ やポリマーの浱度によってほとんど变化が哭め

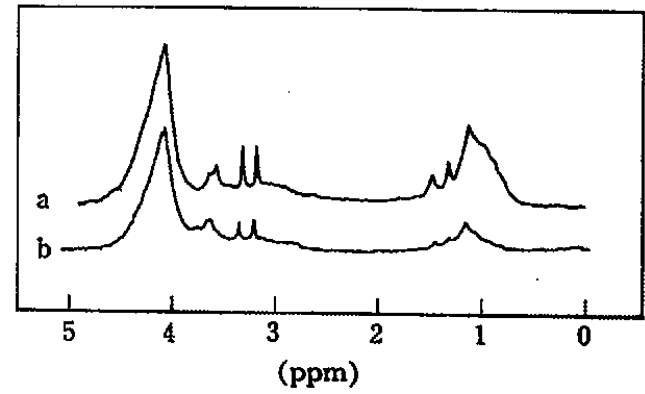

a の湌度はbのポリマー湌度より高い.

図 $23 \mathrm{AlEt}_{3}-\mathrm{BF}_{3} \mathrm{O}\left(\mathrm{C}_{2} \mathrm{H}_{6}\right)_{2}$ を触媒として合成したポソー $(\beta \text {-MGAM })^{a) の ~ N M R ~ ス ヘ ゚ ク ト ル ~}$

注 $a$ ）固体ポリマーをベンぜンに溶かしたもののスペクトル.

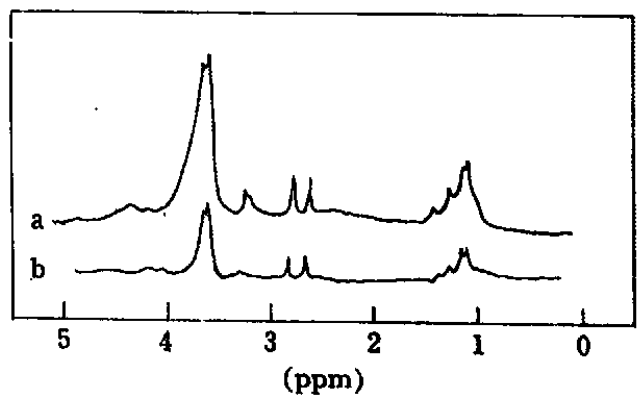

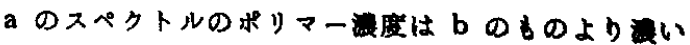
（湠度ははっきりわからない）。

为 $24 \mathrm{AlEt}_{3}-\mathrm{BF}_{3} \mathrm{O}\left(\mathrm{C}_{2} \mathrm{H}_{3}\right)_{2}$ 䖵として合成したポりー $(\beta-\mathrm{MGAM})^{a)}$ の NMR スペクトル

汒a）グリース状ボりマーをべンゼンに浴かしたもののスペ クトル. 


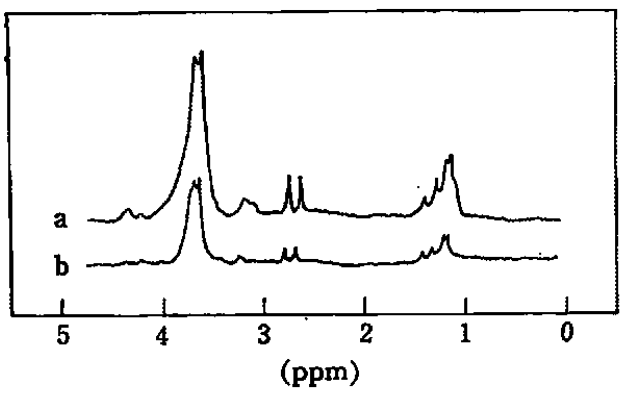

因 25 a $\mathrm{Et}_{2} \mathrm{Zn}-\mathrm{BF}_{3} \mathrm{O}\left(\mathrm{C}_{2} \mathrm{H}_{5}\right)_{2}$ 系を伹媒として合成した ポリ $(\beta-\mathrm{MGAM})^{a)}$ の NMR スペクトル

b $\mathrm{AlEt}_{8}-\mathrm{SnCl}_{4}$ 系を触媒として合成しだ゚゚リー $(\beta$-MGAM)bの NMR スペクトル

注 $a$ ）ダリース状ポリマー。

b) 固体术りマー。

・各ベンぜン溶被の NMR スペクトルを示す.

られなかった(因 19，20，21)。

3.6 ポリ-( $\beta$-MGAM))の NMR スペクトル

ポリマーの NMR スペクトルを測定したが， $\alpha, \beta$ 位の水素原

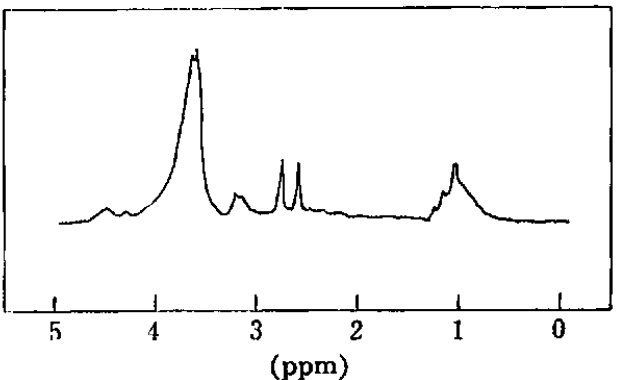

図 $26 \mathrm{AlEt}_{3}-\mathrm{Co}(\mathrm{acac})_{3}$ 系僻媒によって合成した固体 ポリー( $\beta$-MGAM)の NMR スペクトルa)

注 a) ベンゼン溶激中の NMR スペクトルを示す。

子と $\beta$ メチル基のスペクトルは幅広く解析困難であるが，エステ ル基飞基うくくメチル悲のスペクトルは比較的鋭く，このスペクト ルの状態は重合反応の条俳炕って異なり,トリエチルアルミニ ウムー三フッ化ホウ系エーテラートで合成したポりマーのエステ ル基は，分雖しない1本の吸収スペクトルを示した。スペクトル はポリマーの濃度によって影嵬されなかった。

\section{直镍状光学活性ポリー(B-メチルグリシド酸アルキルエステル)の架橋化反応*1}

(明和 40 年 11 月 9 日受理)

\section{島 崎 秀 雄*2}

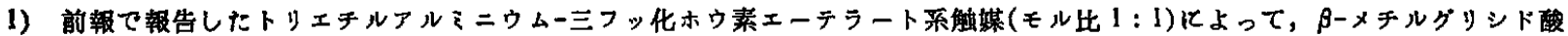

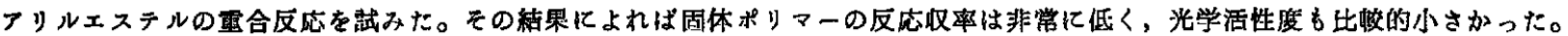

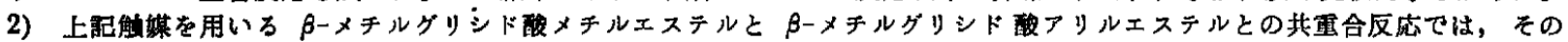
重合初期段階に打いて，雨モノマ一の反応性比がほとんど等しかった。雨モノマーのモル比が約 $51: 49$ の共電合体の比踀光度 $[\alpha]_{\mathrm{Hg}}^{2 \mathrm{~S}^{\circ} \mathrm{C}}$ は $-28.3^{\circ}$ であっだ。

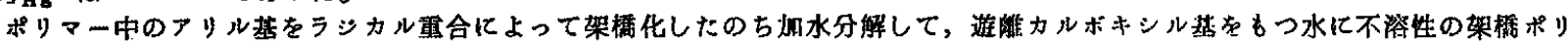
マーを得た。DMF 可溶部のポリマーの比旋光度 $[\alpha]_{\mathrm{D}}^{25^{\circ} \mathrm{C}}$ 法約 $-27^{\circ}$ であった。

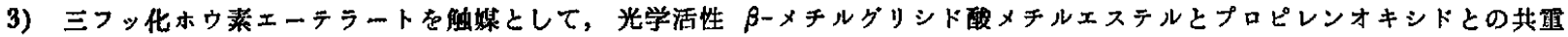
合反応を試みたが，挠者の電合活性は前者と比洨していちじるしく高く，ポりマー肺のプロピレンオキシドの增如とともにポリマ

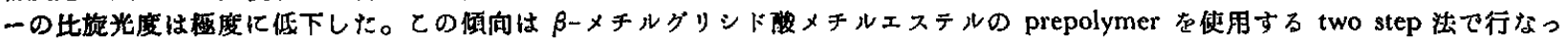
た䙵合反応でも整められた。

\section{1 緒锗}

前報で光学活性な $\beta$-メチルグリシド酸メチルエステル( $\beta$ MGAM と略す)を原料として重合反応を行ない，北学活性なポ リマーを合成したてとを報告した。しかしこのポリマーを加水分 解したあのは水に可溶性で，さきに述べた著者の目的にあわない ものであった。そてで不整炭菜に直結した遊雄カルボキシル㷊 を持つ，水に不溶性の光学活性术リマーを成するために，告 ず光学活性な $\beta$-メチルグリシド破アリルエステル(本鍦では $\beta$ MGAA と略す)を合成して，これから得られたポリエーテルのア リル基の一部を重命反応にあてて架橋ポリマーを介成したのち， 架橋にあずからないアリル基を加水分解して避盛カルボキシル基

*1乙の赧交を“兆学活性ポリエーテルの合成(第 3 報)”と す万；前報（第 2 報），我岎，日化，87，462(1966)。

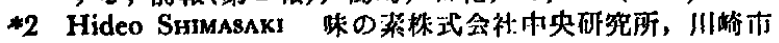
鈴木町
をもつ光学活性ポりマーを合成するととを訊みた。しかしポリマ 一ヤのアリル基を選択的に可合させるととがむずかしく，ポリマ 一中に邂当に分散した遊跳カルボキシル基をもつポリマーを合成 することはできなかった。

つぎ著者は，原料として光学活性な $\beta$-MGAM と $\beta$-MGAA を濑用して其重合反応を行ない，得られた共重合体のアリル装を 正命させて架橾ポリマーを合成した。，

本坡では $\beta$-MGAM と $\beta$-MGAA の共重合反応飞ついて報告 するが, $\beta$-MGAA の単独而合, $\beta$-MGAM とプロピレンオキシ

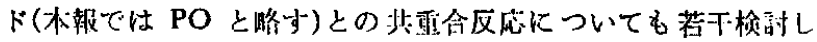
た。

\section{2 実 験 の 部}

\section{1 単曋体}

及-MGAA：さきに述べた $\beta$-MGAMの命成法にしたがってDー 